\title{
Semisynthetic Neoclerodanes as Kappa Opioid Receptor Probes
}

\author{
Kimberly M. Lovell ${ }^{1}$, Tamara Vasiljevik ${ }^{1}$, Juan J. Araya ${ }^{1}$, Anthony Lozama ${ }^{2}$, Katherine M. \\ Prevatt-Smith ${ }^{1}$, Victor W. Day ${ }^{1}$, Christina M. Dersch ${ }^{3}$, Richard B. Rothman ${ }^{3}$, Eduardo R. \\ Butelman $^{4}$, Mary Jeanne Kreek ${ }^{4}$, and Thomas E. Prisinzano ${ }^{1, *}$ \\ ${ }^{1}$ Department of Medicinal Chemistry, The University of Kansas, Lawrence, Kansas 66045 \\ ${ }^{2}$ Division of Medicinal \& Natural Products Chemistry, The University of lowa, lowa City, lowa \\ 52242 \\ ${ }^{3}$ Clinical Psychopharmacology Section, IRP, NIDA, DHHS, Baltimore, Maryland 21224 \\ ${ }^{4}$ Laboratory on the Biology of Addictive Diseases, The Rockefeller University, New York, New \\ York
}

\begin{abstract}
Modification of the furan ring of salvinorin A (1), the main active component of Salvia divinorum, has resulted in novel neoclerodane diterpenes with opioid receptor affinity and activity.

Conversion of the furan ring to an aldehyde at the $\mathrm{C}-12$ position (5) has allowed for the synthesis of analogues with new carbon-carbon bonds at that position. Previous methods for forming these bonds, such as Grignard and Stille conditions, have met with limited success. We report a palladium catalyzed Liebeskind-Srogl cross-coupling reaction of a thioester and a boronic acid that occurs at neutral $\mathrm{pH}$ and ambient temperature to produce ketone analogs at $\mathrm{C}-12$. To the best of our knowledge, this is the first reported usage of the Liebeskind-Srogl reaction to diversify a natural product scaffold. We also describe a one-step protocol for the conversion of $\mathbf{1}$ to 12-epi-1 (3) through microwave irradiation. Previously, this synthetically challenging process has required multiple steps. Additionally, we report in this study that alkene 9 and aromatic analogues 12, 19, $\mathbf{2 3}, \mathbf{2 5}$, and $\mathbf{2 6}$ were discovered to retain affinity and selectivity at kappa opioid receptors (KOP). Finally, we report that the furan-2-yl analog of $\mathbf{1}$ (31) has similar affinity to $\mathbf{1}$. Collectively, these findings suggest that different aromatic groups appended directly to the decalin core may be well tolerated by KOP receptors, and may generate further ligands with affinity and activity at KOP receptors.
\end{abstract}

\section{Introduction}

\begin{abstract}
Psychoactive natural products have played a vital role in the development of treatments for a number of diseases and have advanced our knowledge of basic biological processes in the central nervous system (CNS). ${ }^{1}$ For example, the endogenous opioid and cannabinoid receptor systems were discovered through the systematic study of psychoactive natural products. In addition to the discovery of endogenous opioid and cannabinoid receptor
\end{abstract}

\footnotetext{
(C) 2012 Elsevier Ltd. All rights reserved

* To whom correspondence should be addressed Thomas E. Prisinzano, Ph.D. Associate Professor 1251 Wescoe Hall Drive 4070 Malott Hall Lawrence, Kansas 66045-7582 Phone: (785) 864-3267 Fax: (785) 864-5326 prisinza@ku.edu.

Publisher's Disclaimer: This is a PDF file of an unedited manuscript that has been accepted for publication. As a service to our customers we are providing this early version of the manuscript. The manuscript will undergo copyediting, typesetting, and review of the resulting proof before it is published in its final citable form. Please note that during the production process errors may be discovered which could affect the content, and all legal disclaimers that apply to the journal pertain.

Supporting Information Available X-ray diffraction analysis of 3, as well asHPLC analysis of compounds 3, 8, 9, and 12 - 31.
} 
systems, the investigation of psychoactive natural products has also led to the development of useful biological probes that have advanced our knowledge of the underlying causes of many CNS disorders. ${ }^{2}$ Furthermore, structural modifications of such natural products have led to the development of effective medications to treat a number of CNS disorders. ${ }^{3}$

Presently, combinatorial-based approaches and genomics have largely replaced natural products screening in CNS drug discovery. Even with these advances in technology, CNS drugs entering clinical development have only approximately a 7\% probability of reaching the marketplace, as compared to an industry average of $15 \% .^{4-5}$ Thus, it is imperative to find and explore new chemical scaffolds for CNS drug discovery and development, as well as for potential probes that can be used to further enhance our understanding of neurobiology.

One recent example of a psychoactive natural product is the neoclerodane diterpene, salvinorin A (1) (Figure 1). ${ }^{4-7}$ This natural product is the main active component of the hallucinogenic mint plant Salvia divinorum Epling \& Játiva (Lamiaceae). Historically, $S$. divinorum has been used by the Mazatec Indians of Oaxaca, Mexico in ethnomedicinal practice. ${ }^{8} S$. divinorum is notorious in the public eye for its use as a recreational drug. ${ }^{9}, 10$ Due to its hallucinogenic effects, several countries and states have scheduled $S$. divinorum as a schedule I controlled substance. In 2002, the site of action of $\mathbf{1}$ was identified as opioid (KOP) receptors where $\mathbf{1}$ acts as a high efficacy agonist. ${ }^{4}$ Furthermore, $\mathbf{1}$ appears to have unique properties as a KOP receptor ligand that includes its high efficacy in particular transduction systems and a reduced propensity to cause receptor desensitization. ${ }^{11}, 12$ These findings suggest that $\mathbf{1}$ offers a new chemotype for the development of functionally selective KOP ligands as biological probes. ${ }^{13}$ Additionally, $\mathbf{1}$ is structurally distinct from other known opioid ligands such as U50,488 (2) in that it does not contain a basic nitrogen; a feature traditional opioid pharmacology believed to be required. ${ }^{14-18}$

Currently available KOP receptor ligands, which have become of interest due to the interaction of the KOP/dynorphin system with major neuropsychiatric disorders and addiction, suffer from several therapeutic limitations. First, KOP agonists have been shown to potentiate cocaine reward and produce psychotomimesis, sedation, and nausea. ${ }^{19-22}$ Thus, high efficacy agonism at KOP results in behavioral toxicity and preclinical models support its involvement in endogenous pathophysiology (e.g., anxiety, depression, and addiction). Therefore, partial agonism or antagonism at KOP receptors is a valuable target for medications development. Second, almost all currently available KOP antagonists have a slow onset of action and are extremely long in duration of action. ${ }^{23,} 24$ This makes these agents difficult to use in translational and pharmacokinetic models. Thus, there is a pressing need to develop novel agents and biological probes devoid of these limitations.

One approach to overcoming the limitations of currently available KOP ligands is to identify and develop new chemical scaffolds with improved drug-like characteristics. ${ }^{24-27}$ Another approach is to modify a KOP selective natural product, such as $\mathbf{1}$, into a partial agonist or antagonist through systematic structure-activity relationship studies. To this end, our present investigation looked to answer three questions: (1) what is the effect of configuration of the C-12 position on opioid affinity and activity; (2) can the affinity and/or activity be enhanced from the addition of a suitable group off an aryl ketone analogue; and (3) what is the effect of altering the position of the oxygen atom in the furan ring. Our results are described herein. 


\section{Chemistry}

Salvinorin A (1) was isolated from $S$. divinorum and we developed a one-step protocol for the conversion of 1 to 12-epi-1 (3) through microwave irradiation (Scheme 1). 2,4,4,6Tetrabromocyclohexa-2,5-dienone and $\mathbf{1}$ were dissolved in anhydrous, degassed dichloromethane and irradiated in the microwave for 30 minutes at $130{ }^{\circ} \mathrm{C}$. Purification via column chromatography afforded $\mathbf{3}$ and $\mathbf{4}^{28}$ in $39 \%$ and $30 \%$ yields, respectively. Selective olefination of 1 was envisioned by introduction of an aldehyde at C-12, exploiting the reactivity of the aldehyde relative to the other four carbonyls present in $\mathbf{1}$ (Scheme 2). Aldehyde 5 was obtained following our previously published methods. ${ }^{29}$ Several different olefination reactions were attempted including Wittig and Horner-Wadsworth-Emmons conditions. These methods were ineffective due to low yields, difficulties in purification, and ultimately aldehyde degradation. In the end, success was found using Julia-Kocienski olefination conditions. These conditions are applicable for use with base-sensitive aldehydes and are milder than previously attempted olefination conditions. To obtain the needed JuliaKocienski precursor, synthesis was initiated with 3-furaldehyde that was reduced with $\mathrm{NaBH}_{4}$ to yield the corresponding alcohol 6a in $88 \%$ yield. Alcohol 6a was then displaced with bromine in $45 \%$ yield (6b) and treated with ammonium heptamolybdate tetrahydrateperoxide complex to afford the Julia-Kocienski precursor $\mathbf{7}$ in $86 \%$ yield. ${ }^{30}$ The reaction of $\mathbf{5}$ and $\mathbf{7}$ in the presence of KHMDS afforded alkenes 8 and $\mathbf{9}$ in overall reaction yield of $12 \%$. The individual isomers were isolated by flash column chromatography followed by additional HPLC purification in a 2:1 ratio of $\mathbf{8}$ to $\mathbf{9}$.

Additional furan-modified ketone analogues of $\mathbf{1}$ were synthesized as described in Scheme 3. Many different methods to form carbon-carbon bonds are known in the scientific literature. However, many of these methods are not suitable to highly functionalized or acid/ base-sensitive compounds like $1 .{ }^{31}$ In our hands, Grignard reactions using aldehyde 5 were met with limited success due to poor solubility of $\mathbf{5}$ in THF and ether at low temperatures and resulted in low yields $(0-20 \%)$. Béguin and coworkers were able to synthesize several ketone derivatives through in situ formation of the acid chloride followed by Stille coupling of stannanes in low to moderate yields $(7-57 \%) .{ }^{32}$ This procedure is also limited by the availability and difficulties associated with stannane reagents. To overcome these challenges, an investigation into the suitability of the Liebeskind-Srogl reaction was undertaken. ${ }^{33,34}$ The Liebeskind-Srogl reaction is a palladium catalyzed cross-coupling reaction of a thioester and boronic acid that requires a stoichometric amount of copper (I) additive. ${ }^{27,28}$ This reaction occurs at neutral $\mathrm{pH}$ and room temperature and has previously been utilized on base sensitive substrates. ${ }^{35,36}$ Additionally, an increasing number of boronic acids are commercially available, which further contributes to the convenience of analogue synthesis. With a promising reactivity profile, the thiophenol ester at the $\mathrm{C}-12$ position was synthesized using the same CDMT and $N$-methylmorpholine conditions previously developed with substitution of ethanethiol for thiophenol. ${ }^{29}$ Thioester $\mathbf{1 1}$ was synthesized in $62 \%$ yield. Using bis(dibenzylideneacetone)palladium (0), copper (I) thiophene carboxylate, and triethylphosphite in anhydrous THF, coupling of thioester 11 and desired boronic acids synthesized ketone derivatives $12-29$ in $29-87 \%$ yields. Ketone analogue 30 was synthesized as an intermediate towards the synthesis of a furan-2-yl analogue of salvinorin A (Scheme 4). To access this compound, ketone analogue $\mathbf{3 0}$ was refluxed with $\mathrm{SeO}_{2}$ in bromobenzene. ${ }^{37}$ The initial thought was to isolate the dicarbonyl and use previously developed conditions to cyclize to the furan-2-yl analogue in a two-step procedure. ${ }^{38}$ Fortuitously, cyclization also occurred under oxidative conditions to afford analogue $\mathbf{3 1}$ in $18 \%$ yield from $\mathbf{3 0}$. To the best of our knowledge, this is the first report using the Liebeskind-Srogl reaction to diversify a natural product scaffold. 


\section{Results and Discussion}

The synthesized compounds were evaluated for affinity and efficacy at opioid receptors (Table 1). ${ }^{39}$ It was thought that the analogues prepared would provide greater insight into the potential use of modified neoclerodanes as opioid receptor probes. Our investigation initially began by addressing the effect of configuration at the $\mathrm{C}-12$ position has on opioid affinity and activity. It was envisioned that this alteration would further investigate the amount of structural flexibility tolerated at the binding site of KOP receptors for neoclerodanes. Inversion of this center is synthetically challenging as $\mathbf{1}$ is a highly functionalized neoclerodane diterpene and has shown sensitivity to both acids and bases, ${ }^{31}$ however, 3 was synthesized by Béguin and coworkers in several steps and 19\% overall yield. ${ }^{32}$ NMR and independent X-ray crystallographic data (see supplemental material) were consistent with the previous report. The mechanism for the apparent bond breaking and reforming has not been fully elucidated and is currently under investigation. Compound $\mathbf{3}$ demonstrated similar affinity at KOP receptors to $\mathbf{1}\left(K_{\mathrm{i}}=7.4 \pm 0.7 \mathrm{nM}\right.$ vs. $\left.K_{\mathrm{i}}=17 \pm 1 \mathrm{nM}\right)$. In our hands, $\mathbf{3}$ had a 2 -fold loss in affinity relative to $\mathbf{1}$ however, Béguin and coworkers found $\mathbf{3}$ to have a greater loss in affinity relative to $\mathbf{1} .^{32}$

To facilitate a greater understanding of the steric demands of the furan ring, analogues $\mathbf{8}$ and 9 were prepared. It was envisioned that the synthesis of these analogues would explore the influence of the additional steric bulk in the furan binding site, as well as the preferred orientation of the oxygen atom in the furan ring by constraining its rotation with the addition of the olefin. It was found that the cis analogue 9 had almost 40 -fold higher affinity for the KOP receptor compared to the trans analogue $8\left(K_{\mathrm{i}}=30 \pm 4 \mathrm{nM}\right.$ vs. $\left.K_{\mathrm{i}}=1,120 \pm 30 \mathrm{nM}\right)$. This finding suggests that size plays a key role in the binding of the furan ring substituent given that the extended trans conformation (8) has weaker affinity compared to the cis orientation (9). In addition, it appears that distance from the decalin core plays an important role in the bonding of the furanyl oxygen of $\mathbf{1}$.

Previous investigations have suggested that modification or substitution of the furan ring is tolerated but often diminishes affinity and efficacy at KOP receptors. $29,32,39$ To further explore the potential replacement of the furan ring with other substituents, a series of aryl ketone derivatives were synthesized. Our intention was to identify a more desirable hydrogen bond interaction with the carbonyl and its KOP receptor binding site while potentially accessing another favorable interaction in the binding pocket through judicious choice of a substituent on the aryl ring. Initially, phenyl analogue $\mathbf{1 2}^{\mathbf{3 2}}$ was prepared and found to have decreased affinity compared to $1\left(K_{\mathrm{i}}=70 \pm 3 \mathrm{nM}\right.$ vs. $\left.K_{\mathrm{i}}=7.4 \pm 0.7 \mathrm{nM}\right)$. Based on the $<100 \mathrm{nM}$ affinity and the potential of this scaffold to have greater metabolic stability than furan containing salvinorin A, investigations into the effects of substitutions at the ortho, meta, and para positions were undertaken. Given the many potential possibilities, we elected to selectively probe the effect of a methoxy group and a phenolic group. Our rationale was that we could quickly gauge the role of electron donating properties, as well as the possible effect of hydrogen bond donating compared to hydrogen bond accepting properties on affinity. Introduction of a methoxy group $(\mathbf{1 3}-\mathbf{1 5})$ was found to generally decrease affinity compared to $\mathbf{1 2}$. Of these substitutions, we identified that incorporation of a $m$-methoxy group (14) was best tolerated $\left(K_{\mathrm{i}}=290 \pm 10 \mathrm{nM}\right)$. Similarly, we found that introduction of a phenol group $(\mathbf{1 6}-\mathbf{1 8})$ resulted in generally decreased affinity compared to 12. However, we found that a $m$-phenolic group was best tolerated and had comparable affinity to $12\left(K_{\mathrm{i}}=110 \pm 5 \mathrm{nM}\right.$ vs. $\left.K_{\mathrm{i}}=70 \pm 3 \mathrm{nM}\right)$. Given that meta substitution was best tolerated, we decided to explore additional meta substituents.

We first focused on preparing carboxamide analogue (19) as a nonclassical bioisosteric replacement for the phenol group. Previously, Wentland and coworkers found that this 
structural modification resulted in high affinity analogues at opioid receptors when the 8position hydroxyl of cyclazocine was modified, as well as the 3-position of the morphinan nucleus. ${ }^{40,}{ }^{41}$ Remarkably, carboxamide (19) was identified as having increased affinity approximately 3 -fold compared to $\mathbf{1 7}\left(K_{\mathrm{i}}=40 \pm 1 \mathrm{nM}\right.$ vs. $\left.110 \pm 5 \mathrm{nM}\right)$. Given this finding, we sought to further explore the nature of the increased affinity. Thus we prepared $m$-cyano (20), $m$-trifluoromethoxy (21), and $m$-trifluoromethyl (22). The replacement of the carboxamido group with a cyano moiety decreased affinity 6-fold compared to $\mathbf{1 9}\left(K_{\mathrm{i}}=220\right.$ $\pm 10 \mathrm{nM}$ vs. $K_{\mathrm{i}}=40 \pm 1 \mathrm{nM}$ ). Substitution with a trifluoromethoxy or a trifluoromethyl group also decreased affinity compared to $19\left(K_{\mathrm{i}}>10,000 \mathrm{nM}\right.$ and $K_{\mathrm{i}}=2,260 \pm 120 \mathrm{nM}$, respectively vs. $K_{\mathrm{i}}=40 \pm 1 \mathrm{nM}$ ). These latter findings suggest that the electron withdrawing nature of the carboxamido group is not responsible for the increase in affinity. However, additional analogues will need to be prepared to more definitively prove this point.

The effect of replacing the phenyl group of $\mathbf{1 2}$ was also investigated. These analogues were designed to probe the potential of replacing the benzene ring with several different bioisosteric replacements as well as the necessity of an aromatic ring. The substitution of the benzene ring with a 2 -furan (23) 32 and 3-furan (24) ketone was probed. These changes were well tolerated as $\mathbf{2 3}$ and $\mathbf{2 4}$ were found to have similar affinity to $\mathbf{1 2}\left(K_{\mathrm{i}}=80 \mathrm{nM}\right.$ and $K_{\mathrm{i}}=$ $150 \pm 10 \mathrm{nM}$, respectively vs. $K_{\mathrm{i}}=70 \pm 3 \mathrm{nM}$ ). Given this success, we probed additional replacements of the benzene ring. The substitutions of the phenyl ring with a 2-thiophene $(\mathbf{2 5})^{32}$ and 3-thiophene (26) were found to increase affinity at KOP receptors compared to $12\left(25: K_{\mathrm{i}}=36 \pm 2 \mathrm{nM}, \mathbf{2 6}: K_{\mathrm{i}}=31 \pm 3 \mathrm{nM}\right.$ vs. 12: $\left.K_{\mathrm{i}}=70 \pm 3 \mathrm{nM}\right)$. We then sought to further explore size requirements for the aromatic substituent. To this end, we annulated an additional benzene ring onto 23 (27), 25 (28), and 26 (29). Unfortunately, these changes were not well tolerated and affinity was considerably decreased (27: $K_{\mathrm{i}}>10,000 \mathrm{nM} ; \mathbf{2 8}: K_{\mathrm{i}}$ $=9,210 \mathrm{nM}$ and 29: $\left.K_{\mathrm{i}}>10,000 \mathrm{nM}\right)$. Finally, the necessity of the phenyl was probed by replacing it with a cis-propenyl group (30). This change was not well tolerated and led to a 4-fold decrease in affinity compared to $\mathbf{1 2}\left(K_{\mathrm{i}}=320 \pm 20\right.$ vs. $\left.K_{\mathrm{i}}=70 \pm 3 \mathrm{nM}\right)$. This latter finding is interesting and suggests that an aromatic ring may not be completely necessary for affinity. However, additional alkyl analogues will need to be prepared to confirm this hypothesis. Collectively, these results suggest that affinity of $\mathbf{1 2}$ may be enhanced by the introduction of $m$-carboxamido group (19) or through bioisosteric replacement of the phenyl ring $(\mathbf{2 3}, \mathbf{2 5}$, and 26).

Interestingly, $\mathbf{2 3}$ was found previously to have reduced affinity compared to the present investigation $\left(K_{\mathrm{i}}>1,000 \mathrm{nM}\right.$ vs. $\left.K=80 \mathrm{nM}\right) .{ }^{32}$ The previous report suggested that the lack of affinity seen by $\mathbf{2 3}$ might be the result of instability under the assay conditions. ${ }^{32}$ However, we saw no evidence of stability issues and this may explain the increase in affinity. Another possibility may be the presence of trace impurities not seen in the present investigation. One potential source of impurities is tin byproducts as the previous investigation used Stille coupling conditions. ${ }^{32}$ Our present investigation did not use this type of coupling favoring a more "green" method.

Next, we sought to determine the effect of removing the ketone spacer in 23 (31). Our other motivation was this analogue would provide information on the importance of the position of the oxygen in the furan ring of $\mathbf{1}$ on opioid receptor affinity. Several molecular modeling studies have suggested that the oxygen of the furan ring is directly participating in a hydrogen bond with the KOP receptor. ${ }^{4,42}$ It was envisioned that significant changes in affinity between $\mathbf{1}$ and $\mathbf{3 1}$ would validate the importance of the hydrogen bond between the furanyl oxygen and the KOP receptor. The removal of the ketone spacer resulted in a 9-fold increase in affinity at KOP receptors compared to $23\left(K_{\mathrm{i}}=8.7 \pm 0.4 \mathrm{nM}\right.$ vs. $K_{\mathrm{i}}=80 \pm 4$ $\mathrm{nM})$. This finding suggests that other modifications to the furan ring of $\mathbf{1}$ may also be 
tolerated. While synthetic methods exist for their preparation, ${ }^{43,44}$ their use for structureactivity relationship studies have not been described to date.

Surprisingly, $\mathbf{3 1}$ was found to have almost identical affinity at KOP receptors compared to $\mathbf{1}$ $\left(K_{\mathrm{i}}=8.7 \pm 0.4 \mathrm{nM}\right.$ vs. $K_{\mathrm{i}}=7.4 \pm 0.7 \mathrm{nM}$, respectively). This would suggest that a hydrogen bond exists from the furanyl oxygen of $\mathbf{3 1}$ to the same residue on the KOP receptor as the furanyl oxygen of $\mathbf{1}$. Due to the lack of $\mathbf{1}-\mathrm{KOP}$ receptor co-crystal structure, one way to investigate the possibility of a hydrogen bond is through mutation of residues of the KOP receptor thought to be involved in the binding of $\mathbf{1}$ and observation of the changes to affinity. However, this is beyond the scope of the present investigation.

Selected analogues were then evaluated for their efficacy at KOP receptors using the $\left[{ }^{35} \mathrm{~S}\right] \mathrm{GTP}-\boldsymbol{\gamma}$-S assay (Table 2). 12-Epi-1(3) was found to be 18 -fold less potent than the $\mathbf{1}$ $\left(\mathrm{EC}_{50}=720 \pm 97, \mathrm{E}_{\max }=109 \pm 4 \%\right.$ vs. $\left.\mathrm{EC}_{50}=40 \pm 6 \mathrm{nM}, \mathrm{E}_{\max }=124 \pm 6 \%\right)$. Despite its high affinity, 9 was found to have reduced potency as an agonist in the $\left[{ }^{35} \mathrm{~S}\right] \mathrm{GTP}-\boldsymbol{\gamma}-\mathrm{S}$ assay compared to $1\left(\mathrm{EC}_{50}=1,370 \pm 180 \mathrm{nM}\right.$ vs. $\left.\mathrm{EC}_{50}=40 \pm 6 \mathrm{nM}\right)$. The reasons for this large discrepancy are unclear but may be due to poor solubility under the assay conditions. Phenyl ketone 12 was found to be a partial agonist compared to $1\left(E_{\max }=74 \pm 6\right.$ vs. $E_{\max }=124 \pm$ 6). However, its reduced potency $\left(\mathrm{EC}_{50}=1370 \pm 180 \mathrm{nM}\right.$ vs. $\left.\mathrm{EC}_{50}=40 \pm 6 \mathrm{nM}\right)$ inhibits its utility as a pharmacological probe. Carboxamide 19 was found to have 18 -fold reduced potency in the $\left[{ }^{35} \mathrm{~S}\right] \mathrm{GTP}-\gamma$-S read assay compared to $1\left(\mathrm{EC}_{50}=730 \pm 90 \mathrm{nM}\right.$ vs. $\mathrm{EC}_{50}=40$ $\pm 6 \mathrm{nM}$ ). While there was little difference in affinity for KOP receptors, 26 was found to be approximately 3 -fold more potent than $25\left(\mathrm{EC}_{50}=620 \pm 50 \mathrm{nM}\right.$ vs. $\left.\mathrm{EC}_{50}=1,630 \pm 23 \mathrm{nM}\right)$ as an agonist. The most potent compound identified in the $\left[{ }^{35} \mathrm{~S}\right] \mathrm{GTP}-\gamma-\mathrm{S}$ assay was 2furanyl analogue $\mathbf{3 1}\left(\mathrm{EC}_{50}=140 \pm 10 \mathrm{nM}\right)$. Compound $\mathbf{3 1}$ was found to be 3 -fold less potent than $\mathbf{1}$ as an agonist.

Given these results, we elected to further profile $\mathbf{1 , 1 9}$ and $\mathbf{3 1}$ as KOP agonists using the fluorescent $\mathrm{Ca}^{2+}$ mobilization assay (Table 3). While this particular assay is a more artificial system, it was envisioned that an additional assay would provide insight into the pharmacological properties of these neoclerodanes. In particular, it was thought that this assay would provide further validation of the partial agonist character of $\mathbf{1 9}$ and $\mathbf{3 1}$ when compared to 1 in the $\left[{ }^{35} \mathrm{~S}\right] \mathrm{GTP}-\gamma$-S assay. As seen in the $\left.{ }^{35} \mathrm{~S}\right] \mathrm{GTP}-\gamma-\mathrm{S}$ assay, carboxamide 19 was found to have reduced potency compared to $1\left(\mathrm{EC}_{50}=75.4 \pm 21 \mathrm{nM}\right.$ vs. $\mathrm{EC}_{50}=6.11$ $\pm 0.04 \mathrm{nM})$. However, 19 was found to possess identical efficacy compared to $\mathbf{1}\left(\mathrm{E}_{\max }=97\right.$ \pm 2 vs. $\mathrm{E}_{\max }=97 \pm 5$ ). This finding suggests that the partial agonism seen in the $\left[{ }^{35} \mathrm{~S}\right] \mathrm{GTP}$ $\gamma$-S assay may not be readily translatable to other assays. However, this supposition needs further testing. Also as seen previously, the movement of the furanyl oxygen from the 3position (1) to the 2-position (31) resulted in a 2-fold decrease in potency $\left(\mathrm{EC}_{50}=12.2 \pm 4.4\right.$ $\mathrm{nM}$ vs. $\mathrm{EC}_{50}=6.11 \pm 0.04 \mathrm{nM}$ ). Moreover, $\mathbf{3 1}$ was found to have similar efficacy to $\mathbf{1}$ ( $\mathrm{E}_{\max }$ $=97 \pm 2$ vs. $E_{\max }=97 \pm 8$ ). Collectively these results suggest that the use of several different assays will be necessary to best determine partial agonist activity for KOP receptors.

Finally, we sought to explore the effects of $\mathbf{3}$ in nonhuman primates (Macaca mulatta) using a neuroendocrine biomarker assay compared to $1 .^{45}$ This assay has been previously used to determine potency and apparent efficacy of structurally diverse KOP ligands, and is of translational value since it can be used in rodents, non-human primates, and humans. ${ }^{46,47}$ Previous reports have described $\mathbf{3}$ as a partial agonist when evaluated in the $\left[{ }^{35} \mathrm{~S}\right] \mathrm{GTP}-\boldsymbol{\gamma}-\mathrm{S}$ assay $\left(\mathrm{EC}_{50}=41 \pm 6, \mathrm{E}_{\max }=73 \pm 6\right.$ compared to 2$){ }^{32} \mathrm{~A}$ more recent study describes $\mathbf{3}$ as a full agonist using the $\beta$-arrestin 2 DiscoveRx assay $\left(\mathrm{EC}_{50}=382 \pm 85, \mathrm{E}_{\max }=126 \pm 10\right.$ compared to 1). ${ }^{48}$ The differences in the agonist efficacy seen for $\mathbf{3}$ are likely due to differences in receptor expression level, G-protein signaling, and other cell type dependent 
changes. As seen in Figure 2, the dose-effect curve for $\mathbf{3}$ is parallel to that of $\mathbf{1}$ in this assay, but is rightward-shifted by approximately 10 -fold $\left(\mathrm{ED}_{50}\right.$ values from mean log dose-effect curves were 0.038 and $0.0037 \mathrm{mg} / \mathrm{kg}$, for $\mathbf{3}$ and $\mathbf{1}$, respectively). Therefore, while $\mathbf{3}$ has lower potency than $\mathbf{1}$, there is no clear indication that it is acting as a partial agonist in this in vivo assay, up to the largest dose that could be studied due to solubility limits.

\section{Conclusions}

In efforts to further elucidate the pharmacophore and structure-activity relationships of neoclerodanes at opioid receptors, several furan-modified analogues were synthesized and evaluated. We have developed a one-step protocol for the conversion of $\mathbf{1}$ to 12-epi-1 (3) through microwave irradiation. This methodology should be valuable for further research into the structure-activity relationships of neoclerodanes. We have described to the best of our knowledge, the first reported use of the Liebeskind-Srogl reaction to modify a natural product. Our results show that the insertion of a cis alkene spacer to $\mathbf{1}(\mathbf{9})$ is better tolerated sterically at the binding site compared to a trans alkene spacer (8). Affinity for KOP receptors can be maintained by replacing the furan ring with a phenyl ketone (12). Additional structure-activity relationship studies have shown that affinity of $\mathbf{1 2}$ may be enhanced by the introduction of $m$-carboxamido group (19) or through bioisosteric replacement of the phenyl ring $(\mathbf{2 3}, \mathbf{2 5}$, and 26). Surprisingly, $\mathbf{3 1}$ was found to have almost identical affinity at KOP receptors compared to $1\left(K_{\mathrm{i}}=8.7 \pm 0.4 \mathrm{nM}\right.$ vs. $K_{\mathrm{i}}=7.4 \pm 0.7 \mathrm{nM}$, respectively). This would suggest that a hydrogen bond exists from the furanyl oxygen of $\mathbf{3 1}$ to the same residue on the KOP receptor as the furanyl oxygen of $\mathbf{1}$. This finding also suggests that other modifications to the furan ring of $\mathbf{1}$ may be well tolerated by KOP receptors. Collectively, our results provide further evidence that modification of the furan ring is tolerated and produces analogues with affinity and activity at KOP receptors. Further evaluation of analogue $\mathbf{3 1}$ is currently underway and will be reported in due course.

\section{Experimental Section}

Unless otherwise indicated, all reagents were purchased from commercial suppliers and were used without further purification. Melting points were determined on a ThomasHoover capillary melting apparatus. NMR spectra were recorded on a Bruker DRX-400 with qnp probe or a Bruker AV-500 with cryoprobe using values in ppm (TMS as internal standard) and $J(\mathrm{~Hz})$ assignments of ${ }^{1} \mathrm{H}$ resonance coupling. High resolution mass spectrometry data were collected on either a LCT Premier (Waters Corp., Milford, MA) time of flight mass spectrometer or an Agilent $6890 \mathrm{~N}$ gas chromatograph in conjunction with a quarto Micro GC mass spectrometer (Micromass Ltd, Manchester UK). Thin-layer chromatography (TLC) was performed on $0.25 \mathrm{~mm}$ plates Analtech GHLF silica gel plates using ethyl acetate $/ n$-hexanes, in 1:1 ratio as the solvent system unless otherwise noted. Spots on TLC were visualized by UV ( 254 or $365 \mathrm{~nm}$ ), if applicable, and phosphomolybdic

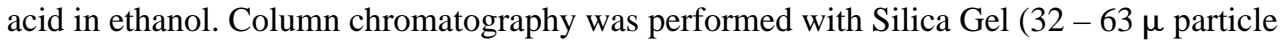
size) from MP Biomedical (Solon, OH). Analytical HPLC was carried out on an Agilent 1100 Series Capillary HPLC system with diode array detection at $209.4 \mathrm{~nm}$ on an Agilent Eclipse XDB-C18 column $(250 \times 10 \mathrm{~mm}, 5 \mu \mathrm{m})$ with isocratic elution in $60 \% \mathrm{CH}_{3} \mathrm{CN} / 40 \%$ $\mathrm{H}_{2} \mathrm{O}$ at a flow rate of $5.0 \mathrm{~mL} / \mathrm{min}$ unless otherwise noted, or on a Phenomenex Luna C18 column $(250 \times 10 \mathrm{~mm}, 5 \mu \mathrm{m})$ with isocratic elution in $60 \% \mathrm{CH}_{3} \mathrm{CN} / 40 \% \mathrm{H}_{2} \mathrm{O}$ unless otherwise noted. The systematic name for salvinorin A $(\mathbf{1})$ is $(2 S, 4 \mathrm{a} R, 6 \mathrm{a} R, 7 R, 9 S, 10 \mathrm{a} S$, $10 \mathrm{~b} R$ )-methyl 9-acetoxy-2-(furan-3-yl)-6a,10b-dimethyl-4,10-dioxo-dodecahydro-1 $H$ benzo[f $]$ iso-chromene-7-carboxylate. Salvinorin A was isolated from $S$. divinorum as previously described. ${ }^{49}$ 
5.1. Preparation of $(2 R, 4 a R, 6 a R, 7 R, 9 S, 10 a S, 10 b R)-m e t h y l$ 9-acetoxy-2-(furan-3-yl)-6a,10bdimethyl-4,10-dioxododecahydro-1H-benzo[f]isochromene-7-carboxylate (3)

In a $20 \mathrm{~mL}$ microwave tube, a solution of $\mathbf{1}(100 \mathrm{mg}, 0.231 \mathrm{mmol}, 1$ equiv) in anhydrous $\mathrm{CH}_{2} \mathrm{Cl}_{2}$ (15 mL), 2,4,4,6-tetrabromocyclohexa-2,5-dienone (113.7 mg, $0.277 \mathrm{mmol}, 1.2$ equiv) was added. The tube was sealed and irradiated in the microwave for 30 minutes at $130{ }^{\circ} \mathrm{C}$. Solvent was removed under reduced pressure and the resulting residue was purified via column chromatography using ethyl acetate, MTBE, and $n$-hexanes to afford $29 \mathrm{mg}$ (39\% yield borsm) as a white solid. HPLC $t=11.463 \mathrm{~min}$; purity $=96.07 \%$. The ${ }^{1} \mathrm{H}$ and ${ }^{13} \mathrm{C}$ spectra in $\mathrm{CDCl}_{3}$, melting point, and HRMS of $\mathbf{3}$ were as previously reported. ${ }^{32} \mathrm{X}$-ray diffraction quality crystals were prepared by recrystallizing 3 from a mixture of EtOAc/ nhexanes.

5.2. Preparation of (4aR,6aR,7R,9S,10aS,10bR)-methyl 9-acetoxy-2-((E)-2-(furan-3yl)vinyl)-6a,10bdimethyl-4,10-dioxododecahydro-1H-benzo[f]isochromene-7-carboxylate (8) and (4aR,6aR,7R,9S,10aS,10bR)-methyl 9-acetoxy-2-((Z)-2-(furan-3-yl)vinyl)-6a,10bdimethyl-4,10-dioxododecahydro-1H-benzo[f]isochromene-7-carboxylate (9)

KHMDS (1.64 $\mathrm{mL}$ of a $0.5 \mathrm{M}$ solution in toluene, $0.83 \mathrm{mmol}$ ) was added in a dropwise manner to a cooled $\left(-78^{\circ} \mathrm{C}\right)$ solution of $7^{30}(263 \mathrm{mg}, 0.91 \mathrm{mmol})$ in THF $(9 \mathrm{~mL})$. After 30 min, a cooled solution of aldehyde $\mathbf{5}(300 \mathrm{mg}, 0.761 \mathrm{mmol})$ in THF $(20 \mathrm{~mL})$ was added in a dropwise manner over 3 minutes. The reaction mixture was stirred at $-78{ }^{\circ} \mathrm{C}$ for 2 hours or until completion and then it was diluted with EtOAc $(9 \mathrm{~mL})$ and quenched by the addition of $\mathrm{H}_{2} \mathrm{O}(10 \mathrm{~mL})$. After warming to room temperature over $30 \mathrm{~min}$, the phases were separated and the aqueous phase was extracted with EtOAc $(2 \times 10 \mathrm{~mL})$. The combined organic extracts were washed with brine $(2 \times 10 \mathrm{~mL})$ and dried over $\mathrm{Na}_{2} \mathrm{SO}_{4}$. Filtration and concentration under reduced pressure afforded $\mathbf{8}$ and $\mathbf{9}$ as a 2:1 mixture, which was separated by flash column chromatography to afford, in order of elution, major isomer $\mathbf{8}$ as a white solid and the minor isomer 9 also as a white solid. The minor isomer was further purified by HPLC $\left(40 \% \mathrm{CH}_{3} \mathrm{CN} / 60 \% \mathrm{H}_{2} \mathrm{O}\right.$ ) on an Agilent Eclipse XDB-C18 column ( $250 \times$ $10 \mathrm{~mm}, 5 \mu \mathrm{m})$ at a flow rate of $5 \mathrm{~mL} / \mathrm{min}$.

8: Isolated as an off-white solid ( $25 \mathrm{mg}, 7.2 \%$ yield) of trans isomer after purification; $\mathrm{mp}=$ $192-194^{\circ} \mathrm{C} ;{ }^{1} \mathrm{H}$ NMR $\left(500 \mathrm{MHz}, \mathrm{CDCl}_{3}\right) \delta 7.45(\mathrm{~s}, 1 \mathrm{H}), 7.39(\mathrm{~s}, 1 \mathrm{H}), 6.51(\mathrm{~d}, J=13.0 \mathrm{~Hz}$, 2H), 5.88 (dd, $J=6.3,15.8 \mathrm{~Hz}, 1 \mathrm{H}), 5.15(\mathrm{~d}, J=9.7 \mathrm{~Hz}, 2 \mathrm{H}), 3.76(\mathrm{~s}, 3 \mathrm{H}), 2.77$ (d, $J=8.1$ $\mathrm{Hz}, 1 \mathrm{H}), 2.43(\mathrm{~d}, J=8.3 \mathrm{~Hz}, 1 \mathrm{H}), 2.34(\mathrm{~d}, J=9.9 \mathrm{~Hz}, 2 \mathrm{H}), 2.20(\mathrm{~s}, 3 \mathrm{H}), 2.18(\mathrm{~s}, 1 \mathrm{H}), 2.05$ $(\mathrm{s}, 1 \mathrm{H}), 1.84(\mathrm{~s}, 1 \mathrm{H}), 1.63(\mathrm{~s}, 3 \mathrm{H}), 1.45(\mathrm{~s}, 3 \mathrm{H}), 1.14(\mathrm{~s}, 3 \mathrm{H}) .{ }^{13} \mathrm{C} \mathrm{NMR}\left(126 \mathrm{MHz}, \mathrm{CDCl}_{3}\right) \delta$ $201.85,171.38,171.06,169.84,143.57,141.07,126.66,122.82,121.74,107.15,77.40$, 74.92, 63.96, 53.46, 51.82, 51.17, 42.89, 41.96, 38.05, 35.17, 30.56, 20.40, 17.95, 16.19, 15.04. HRMS (m/z): [M+Na] calcd for $\mathrm{C}_{25} \mathrm{H}_{30} \mathrm{O}_{8} \mathrm{Na}, 481.1838$; found, 481.1832. HPLC $t_{\mathrm{R}}=$ 8.832 min; purity $=98.21 \%$.

9: Isolated as a white solid ( $15 \mathrm{mg}, 4.3 \%$ yield) of cis isomer after purification; $\mathrm{mp}=182$ $184{ }^{\circ} \mathrm{C} .{ }^{1} \mathrm{H}$ NMR $\left(500 \mathrm{MHz}, \mathrm{CDCl}_{3}\right) \delta 7.52(\mathrm{~s}, 1 \mathrm{H}), 7.45(\mathrm{~s}, 1 \mathrm{H}), 6.45(\mathrm{~s}, 1 \mathrm{H}), 6.40(\mathrm{~d}, J=$ $11.2 \mathrm{~Hz}, 1 \mathrm{H}), 5.54(\mathrm{~d}, J=11.2 \mathrm{~Hz}, 1 \mathrm{H}), 5.47-5.41(\mathrm{~m}, 1 \mathrm{H}), 5.20-5.15(\mathrm{~m}, 1 \mathrm{H}), 3.76(\mathrm{~s}$, $3 \mathrm{H}), 2.81-2.75(\mathrm{~m}, 1 \mathrm{H}), 2.34(\mathrm{~d}, J=9.9 \mathrm{~Hz}, 4 \mathrm{H}), 2.20(\mathrm{~s}, 3 \mathrm{H}), 2.18(\mathrm{~s}, 1 \mathrm{H}), 2.09-2.04(\mathrm{~m}$, $1 \mathrm{H}), 1.84-1.79(\mathrm{~m}, 1 \mathrm{H}), 1.63(\mathrm{~s}, 3 \mathrm{H}), 1.45(\mathrm{~s}, 3 \mathrm{H}), 1.14(\mathrm{~s}, 3 \mathrm{H}) .{ }^{13} \mathrm{C} \mathrm{NMR}(126 \mathrm{MHz}$, $\left.\mathrm{CDCl}_{3}\right) \delta 202.14,171.81,171.47,170.21,143.76,142.04,128.49,124.02,121.01,110.94$, 75.23, 74.12, 64.36, 53.84, 52.23, 51.65, 43.04, 42.30, 38.44, 35.70, 30.99, 20.83, 18.36, 16.65, 15.52. HRMS (m/z): [M+Na] calcd for $\mathrm{C}_{25} \mathrm{H}_{30} \mathrm{O}_{8} \mathrm{Na}, 481$. 1838; found, 481.1830. HPLC $t_{\mathrm{R}}=8.691 \mathrm{~min}$; purity $=100 \%$. 
5.3. Preparation of $(2 S, 4 \mathrm{a} R, 6 \mathrm{a} R, 7 R, 9 S, 10 \mathrm{a} S, 10 \mathrm{~b} R)$-methyl 9-acetoxy-6a,10b-dimethyl-4,10dioxo-2-(phenyl-thiocarbonyl)dodecahydro-1 H-benzo[f $f$ isochromene-7-carboxylate (11)

To an oven dried round bottom flask under argon was added acid $\mathbf{1 0}^{28}(0.64 \mathrm{~g}, 1.57 \mathrm{mmol}, 1$ equiv), CDMT (0.84 g, $4.72 \mathrm{mmol}, 3$ equiv), $N$-methylmorpholine (1.04 mL, $9.44 \mathrm{mmol}, 6$ equiv) followed by the addition of anhydrous THF $(20 \mathrm{~mL})$. After 1 hour, thiophenol $(0.48$ $\mathrm{mL}, 4.72 \mathrm{mmol}, 3$ equiv) was added and reaction stirred at room temperature for 48 hours. The reaction was quenched with $\mathrm{H}_{2} \mathrm{O}(25 \mathrm{~mL})$ and extracted with $\mathrm{Et}_{2} \mathrm{O}(3 \times 30 \mathrm{~mL})$. The combined $\mathrm{Et}_{2} \mathrm{O}$ portion was washed with saturated aqueous $\mathrm{NaHCO}_{3}(3 \times 20 \mathrm{~mL}), 2 \mathrm{~N} \mathrm{HCl}$ $(3 \times 20 \mathrm{~mL})$, brine $(3 \times 20 \mathrm{~mL})$, and dried over anhydrous $\mathrm{Na}_{2} \mathrm{SO}_{4}$. The solvent was evaporated in vacuo and the resulting residue purified by flash column chromatography on silica gel using mixtures of EtOAc/n-hexanes and triturated in EtOAc/n-hexanes to afford $0.4912 \mathrm{~g}\left(62 \%\right.$ yield) of $\mathbf{1 1}$ as a white solid, mp $136-140{ }^{\circ} \mathrm{C} ;{ }^{1} \mathrm{H}$ NMR $\left(500 \mathrm{MHz}, \mathrm{CDCl}_{3}\right)$ $\delta 7.47-7.38(\mathrm{~m}, 5 \mathrm{H}), 5.14(\mathrm{dd}, J=8.6,11.6 \mathrm{~Hz}, 1 \mathrm{H}), 5.09(\mathrm{dd}, J=7.2,9.6 \mathrm{~Hz}, 1 \mathrm{H}), 3.72$ (s, $3 \mathrm{H}), 2.74(\mathrm{dd}, J=5.2,11.6 \mathrm{~Hz}, 1 \mathrm{H}), 2.65(\mathrm{dd}, J=7.2,13.7 \mathrm{~Hz}, 1 \mathrm{H}), 2.37-2.22(\mathrm{~m}, 2 \mathrm{H})$, $2.22-2.10(\mathrm{~m}, 6 \mathrm{H}), 1.84-1.74(\mathrm{~m}, 1 \mathrm{H}), 1.74-1.50(\mathrm{~m}, 3 \mathrm{H}), 1.39(\mathrm{~s}, 3 \mathrm{H}), 1.09(\mathrm{~s}$, $3 \mathrm{H}) .{ }^{13} \mathrm{C}$ NMR $\left(126 \mathrm{MHz}, \mathrm{CDCl}_{3}\right) \delta 201.80,197.76,171.71,170.01,169.87,134.91$, $130.09,129.62,126.07,80.51,75.03,64.39,53.56,52.21,50.64,42.17,39.52,37.96,35.68$, $30.89,20.77,18.38,16.38,16.20$. HRMS $(\mathrm{m} / \mathrm{z})$ : $[\mathrm{M}+\mathrm{H}]$ calcd for $\mathrm{C}_{26} \mathrm{H}_{31} \mathrm{O}_{8} \mathrm{~S}, 503.1740$; found 503.1720 . HPLC $t_{\mathrm{R}}=8.507 \mathrm{~min}$; purity $=>99.99 \%$.

\subsection{General Procedure for Boronic Acid Coupling}

A solution of $\mathbf{1 1}$ (1 equiv), appropriate boronic acid (3 equiv), copper (I) thiophene-2carboxylate (1.5 equiv), and bis(dibenzylideneacetone)palladium( 0 ) $(5 \mathrm{~mol} \%)$ in anhydrous THF under argon was stirred at room temperature. To the stirring solution, triethylphosphite (20 mol \%) was added. The reaction mixture was stirred at room temperature and monitored by TLC until complete. Reactions were typically complete in $2-5$ hours. The mixture was then washed with saturated aqueous $\mathrm{NaHCO}_{3}(3 \times 15 \mathrm{~mL})$, brine $(15 \mathrm{~mL})$ and dried over anhydrous $\mathrm{Na}_{2} \mathrm{SO}_{4}$. The solvent was evaporated in vacuo and the resulting residue purified by flash column chromatography on silica gel using mixtures of EtOAc/n-hexanes and triturated in EtOAc/n-hexanes to afford the desired product.

\subsection{1. (2S,4aR,6aR,7R,9S,10aS,10bR)-methyl 9-acetoxy-2-benzoyl-6a,10b- dimethyl-4,10-dioxododecahydro-1 $H$-benzo[ $f$ ]isochromene-7-carboxylate (12) \\ -Compound 12 was synthesized from compound $\mathbf{1 1}$ using the general procedure and phenylboronic acid to afford $0.221 \mathrm{~g}(82.4 \%)$ isolated as an off-white solid, $\mathrm{mp}=164-167$ ${ }^{\circ} \mathrm{C}$. HRMS ( $\left.\mathrm{m} / \mathrm{z}\right)$ : $[\mathrm{M}+\mathrm{Na}]$ calcd for $\mathrm{C}_{26} \mathrm{H}_{30} \mathrm{O}_{8} \mathrm{Na}, 493.1838$; found 493.1819. HPLC $t_{\mathrm{R}}=$ 6.003 min; purity $=95.36 \%$. The ${ }^{1} \mathrm{H}$ NMR and ${ }^{13} \mathrm{C}$ NMR spectra were in agreement with that previously reported. ${ }^{32}$}

\subsection{2. (2S,4aR,6aR,7R,9S,10aS,10bR)-methyl 9-acetoxy-2-(2- methoxybenzoyl)-6a,10b-dimethyl-4,10-dioxododecahydro-1 $\mathrm{H}$ - benzo[ $f]$ isochromene-7-carboxylate (13)—Compound 13 was synthesized from} compound 11 using the general procedure and 2-methoxyphenylboronic acid to afford 0.082 $\mathrm{g}(66.2 \%)$ isolated as a white solid, $\mathrm{mp}=186-188{ }^{\circ} \mathrm{C} .{ }^{1} \mathrm{H} \mathrm{NMR}\left(500 \mathrm{MHz}, \mathrm{CDCl}_{3}\right) \delta 7.79$ $(\mathrm{dd}, J=1.8,7.8 \mathrm{~Hz}, 1 \mathrm{H}), 7.56-7.47(\mathrm{~m}, 1 \mathrm{H}), 7.07-6.99(\mathrm{~m}, 1 \mathrm{H}), 6.96(\mathrm{~d}, J=8.2 \mathrm{~Hz}, 1 \mathrm{H})$, $5.89(\mathrm{t}, J=8.1 \mathrm{~Hz}, 1 \mathrm{H}), 5.10-5.02(\mathrm{~m}, 1 \mathrm{H}), 3.92(\mathrm{~s}, 3 \mathrm{H}), 3.69(\mathrm{~s}, 3 \mathrm{H}), 2.75-2.63(\mathrm{~m}, 2 \mathrm{H})$, $2.30-2.19(\mathrm{~m}, 2 \mathrm{H}), 2.16-2.06(\mathrm{~m}, 6 \mathrm{H}), 1.72(\mathrm{dt}, J=3.2,13.3 \mathrm{~Hz}, 1 \mathrm{H}), 1.68-1.46(\mathrm{~m}$, $3 \mathrm{H}), 1.40$ (s, 3H), 1.05 (s, 3H). ${ }^{13} \mathrm{C}$ NMR $\left(126 \mathrm{MHz}, \mathrm{CDCl}_{3}\right) \delta 202.11,197.37,171.83$, $171.72,169.99,159.03,135.43,131.80,124.34,121.47,112.15,79.32,75.08,65.20,55.96$, 53.51, 52.16, 49.69, 42.24, 38.20, 38.08, 35.76, 30.96, 20.84, 18.51, 16.90, 16.26. HRMS $(\mathrm{m} / \mathrm{z}):\left[\mathrm{M}+\mathrm{NH}_{4}\right]$ calcd for $\mathrm{C}_{27} \mathrm{H}_{36} \mathrm{O}_{9} \mathrm{~N}, 518.2390$; found 518.2369. HPLC $t_{\mathrm{R}}=6.040 \mathrm{~min}$; purity $=>99.99 \%$ 
5.4.3. (2S,4aR,6aR,7R,9S,10aS,10bR)-methyl 9-acetoxy-2-(3methoxybenzoyl)-6a,10b-dimethyl-4,10-dioxododecahydro- $1 \mathrm{H}$ benzo[ $f$ ] isochromene-7-carboxylate (14)-Compound 14 was synthesized from compound 11 using the general procedure and 3-methoxyphenylboronic acid to afford 0.093 $\mathrm{g}(60.9 \%)$ isolated as a white solid, $\mathrm{mp}=162-164{ }^{\circ} \mathrm{C} .{ }^{1} \mathrm{H}$ NMR $\left(500 \mathrm{MHz}, \mathrm{CDCl}_{3}\right) \delta 7.48$ $-7.43(\mathrm{~m}, 2 \mathrm{H}), 7.40(\mathrm{dd}, J=5.8,10.3 \mathrm{~Hz}, 1 \mathrm{H}), 7.16(\mathrm{ddd}, J=1.1,2.6,8.1 \mathrm{~Hz}, 1 \mathrm{H}), 5.86(\mathrm{t}, J$ $=8.3 \mathrm{~Hz}, 1 \mathrm{H}), 5.16-5.06(\mathrm{~m}, 1 \mathrm{H}), 3.86(\mathrm{~s}, 3 \mathrm{H}), 3.72(\mathrm{~s}, 3 \mathrm{H}), 2.77-2.61(\mathrm{~m}, 2 \mathrm{H}), 2.28(\mathrm{dd}$, $J=7.1,13.5 \mathrm{~Hz}, 2 \mathrm{H}), 2.20-2.09(\mathrm{~m}, 6 \mathrm{H}), 1.80-1.73(\mathrm{~m}, 1 \mathrm{H}), 1.67(\mathrm{dt}, J=8.0,14.9 \mathrm{~Hz}$, $1 \mathrm{H}), 1.62-1.52(\mathrm{~m}, 2 \mathrm{H}), 1.46(\mathrm{~s}, 3 \mathrm{H}), 1.08(\mathrm{~s}, 3 \mathrm{H}) .{ }^{13} \mathrm{C} \mathrm{NMR}\left(126 \mathrm{MHz}, \mathrm{CDCl}_{3}\right) \delta 202.16$, 195.34, 171.78, 171.14, 170.04, 160.31, 134.96, 130.32, 121.55, 121.08, 113.35, 75.51, 75.04, 65.02, 55.72, 53.45, 52.18, 49.49, 42.19, 38.59, 37.92, 35.79, 30.89, 20.80, 18.46, 16.93, 16.21. HRMS $(\mathrm{m} / \mathrm{z})$ : $[\mathrm{M}+\mathrm{H}]$ calcd for $\mathrm{C}_{27} \mathrm{H}_{33} \mathrm{O}_{9}, 501.2125$; found 501.2112. HPLC $t_{\mathrm{R}}=6.217 \mathrm{~min}$; purity $=99.03 \%$.

\subsection{4. (2S,4aR,6aR,7R,9S,10aS,10bR)-methyl 9-acetoxy-2-(4-} methoxybenzoyl)-6a,10b-dimethyl-4,10-dioxododecahydro-1 $\mathrm{H}$ benzo[f]isochromene-7-carboxylate (15)—Compound 15 was synthesized from compound 11 using the general procedure and 4-methoxyphenylboronic acid to afford 0.069 $\mathrm{g}(50.7 \%)$ isolated as a white solid, $\mathrm{mp}=117-120{ }^{\circ} \mathrm{C} .{ }^{1} \mathrm{H}$ NMR $\left(500 \mathrm{MHz}, \mathrm{CDCl}_{3}\right) \delta 7.90$ $-7.85(\mathrm{~m}, 2 \mathrm{H}), 6.97-6.91(\mathrm{~m}, 2 \mathrm{H}), 5.81(\mathrm{t}, J=8.2 \mathrm{~Hz}, 1 \mathrm{H}), 5.14-5.01(\mathrm{~m}, 1 \mathrm{H}), 3.87(\mathrm{~d}, J$ $=7.1 \mathrm{~Hz}, 3 \mathrm{H}), 3.69(\mathrm{~s}, 3 \mathrm{H}), 2.74-2.65(\mathrm{~m}, 1 \mathrm{H}), 2.62(\mathrm{dd}, J=8.7,13.6 \mathrm{~Hz}, 1 \mathrm{H}), 2.25(\mathrm{dd}, J$ $=6.7,13.8 \mathrm{~Hz}, 2 \mathrm{H}), 2.20-2.05(\mathrm{~m}, 6 \mathrm{H}), 1.75-1.47(\mathrm{~m}, 4 \mathrm{H}), 1.43(\mathrm{~s}, 3 \mathrm{H}), 1.05(\mathrm{~s}, 3 \mathrm{H}) .{ }^{13} \mathrm{C}$ NMR $\left(126 \mathrm{MHz}, \mathrm{CDCl}_{3}\right) \delta 202.25,193.81,171.82,171.36,170.07,164.65,131.56,126.54$, 114.55, 75.19, 75.08, 65.08, 55.81, 53.45, 52.18, 49.37, 42.21, 38.59, 37.93, 35.73, 30.90, 20.81, 18.47, 17.08, 16.20. HRMS $(\mathrm{m} / \mathrm{z})$ : $\left[\mathrm{M}+\mathrm{NH}_{4}\right]$ calcd for $\mathrm{C}_{27} \mathrm{H}_{36} \mathrm{O}_{9} \mathrm{~N}, 518.2390$; found 518.2379. $\mathrm{HPLC} t_{\mathrm{R}}=6.247 \mathrm{~min}$; purity $=96.68 \%$.

\subsection{5. (2S,4aR,6aR,7R,9S,10aS,10bR)-methyl 9-acetoxy-2-(2- hydroxybenzoyl)-6a,10b-dimethyl-4,10-dioxododecahydro- $1 \mathrm{H}$ -} benzo[f]isochromene-7-carboxylate (16)-Compound 16 was synthesized from compound $\mathbf{1 1}$ using the general procedure and 2-hydroxybenzeneboronic acid to afford $0.090 \mathrm{~g}(44.0 \%)$ isolated as a white solid, $\mathrm{mp}=200-203{ }^{\circ} \mathrm{C} .{ }^{1} \mathrm{H}$ NMR $\left(500 \mathrm{MHz}, \mathrm{CDCl}_{3}\right)$ $\delta 11.73(\mathrm{~s}, 1 \mathrm{H}), 7.58(\mathrm{~d}, J=8.1 \mathrm{~Hz}, 1 \mathrm{H}), 7.53(\mathrm{t}, J=7.8 \mathrm{~Hz}, 1 \mathrm{H}), 7.03(\mathrm{~d}, J=8.5 \mathrm{~Hz}, 1 \mathrm{H})$, $6.95(\mathrm{t}, J=7.6 \mathrm{~Hz}, 1 \mathrm{H}), 5.92(\mathrm{t}, J=8.4 \mathrm{~Hz}, 1 \mathrm{H}), 5.10(\mathrm{t}, J=10.0 \mathrm{~Hz}, 1 \mathrm{H}), 3.72(\mathrm{~s}, 3 \mathrm{H}), 2.72$ $(\mathrm{dd}, J=8.7,13.8 \mathrm{~Hz}, 2 \mathrm{H}), 2.28(\mathrm{dd}, J=6.8,13.4 \mathrm{~Hz}, 2 \mathrm{H}), 2.23-2.09(\mathrm{~m}, 6 \mathrm{H}), 1.84-1.56$ (m, 4H), 1.47 (s, 3H), 1.09 (s, 3H). ${ }^{13} \mathrm{C}$ NMR $\left(126 \mathrm{MHz}, \mathrm{CDCl}_{3}\right) \delta 202.20,200.58,171.74$, 170.98, 170.06, 163.70, 137.98, 129.64, 119.97, 119.25, 116.55, 75.08, 74.43, 64.96, 53.46, $52.22,49.49,42.23,38.94,37.93,35.83,30.88,20.79,18.49,16.82,16.22$. HRMS $(\mathrm{m} / \mathrm{z})$ : $[\mathrm{M}-\mathrm{H}]$ calcd for $\mathrm{C}_{26} \mathrm{H}_{29} \mathrm{O}_{9}, 485.1812$; found 485.1808 . HPLC $t_{\mathrm{R}}=6.986 \mathrm{~min}$; purity = $96.16 \%$.

\subsection{6. (2S,4aR,6aR,7R,9S,10aS,10bR)-methyl 9-acetoxy-2-(3- hydroxybenzoyl)-6a,10b-dimethyl-4,10-dioxododecahydro- $1 \mathrm{H}$ -} benzo[f]isochromene-7-carboxylate (17)—Compound 17 was synthesized from compound $\mathbf{1 1}$ using the general procedure and 3-hydroxyphenylboronic acid to afford 0.033 $\mathrm{g}(28.9 \%)$ isolated as a white solid, $\mathrm{mp}=131-135{ }^{\circ} \mathrm{C} .{ }^{1} \mathrm{H} \mathrm{NMR}\left(500 \mathrm{MHz}, \mathrm{CDCl}_{3}\right) \delta 7.23$ $(\mathrm{t}, J=7.9 \mathrm{~Hz}, 1 \mathrm{H}), 7.16-7.12(\mathrm{~m}, 1 \mathrm{H}), 7.10(\mathrm{~d}, J=7.8 \mathrm{~Hz}, 1 \mathrm{H}), 6.96(\mathrm{~s}, 1 \mathrm{H}), 6.92(\mathrm{dd}, J=$ $1.9,8.1 \mathrm{~Hz}, 1 \mathrm{H}), 5.78(\mathrm{dd}, J=6.9,10.2 \mathrm{~Hz}, 1 \mathrm{H}), 5.17(\mathrm{dd}, J=8.0,12.1 \mathrm{~Hz}, 1 \mathrm{H}), 3.73(\mathrm{~d}, J=$ $2.0,3 \mathrm{H}), 3.00-2.89(\mathrm{~m}, 2 \mathrm{H}), 2.82(\mathrm{dd}, J=10.3,13.4 \mathrm{~Hz}, 1 \mathrm{H}), 2.37-2.25(\mathrm{~m}, 2 \mathrm{H}), 2.21(\mathrm{~s}$, $3 \mathrm{H}), 2.19-2.09(\mathrm{~m}, 2 \mathrm{H}), 1.84(\mathrm{~d}, J=9.8 \mathrm{~Hz}, 1 \mathrm{H}), 1.78-1.62(\mathrm{~m}, 3 \mathrm{H}), 1.48(\mathrm{~s}, 3 \mathrm{H}), 1.07(\mathrm{~s}$, $3 \mathrm{H}) .{ }^{13} \mathrm{C}$ NMR $\left(126 \mathrm{MHz}, \mathrm{CDCl}_{3}\right) \delta 202.84,196.51,172.04,171.73,171.59,157.11$, 133.45, 130.47, 122.70, 120.61, 114.06, 76.42, 75.37, 63.95, 52.94, 52.19, 48.83, 42.71, 
38.75, 37.79, 35.85, 30.81, 21.00, 18.82, 17.22, 16.13. HRMS ( $\mathrm{m} / \mathrm{z}):[\mathrm{M}-\mathrm{H}]$ calcd for $\mathrm{C}_{26} \mathrm{H}_{29} \mathrm{O}_{9}, 485.1812$; found 485.1801 . HPLC $t_{\mathrm{R}}=4.286 \mathrm{~min}$; purity $=99.66 \%$.

\subsection{7. $(2 S, 4 \mathrm{a} R, 6 \mathrm{a} R, 7 R, 9 S, 10 \mathrm{a} S, 10 \mathrm{~b} R)$-methyl 9-acetoxy-2-(4- hydroxybenzoyl)-6a,10b-dimethyl-4,10-dioxododecahydro- $1 \mathrm{H}$ - benzo[ $f$ ]isochromene-7-carboxylate (18)—Compound 18 was synthesized from} compound $\mathbf{1 1}$ using the general procedure and 4-hydroxyphenylboronic acid to afford 0.092 $\mathrm{g}(68.0 \%)$ isolated as a white solid, $\mathrm{mp}=232-236{ }^{\circ} \mathrm{C} .{ }^{1} \mathrm{H}$ NMR $\left(500 \mathrm{MHz}, \mathrm{CDCl}_{3}\right) \delta 7.82$ $(\mathrm{d}, J=8.8 \mathrm{~Hz}, 2 \mathrm{H}), 6.85(\mathrm{~d}, J=8.8 \mathrm{~Hz}, 2 \mathrm{H}), 6.16(\mathrm{~s}, 1 \mathrm{H}), 5.80(\mathrm{t}, J=8.3 \mathrm{~Hz}, 1 \mathrm{H}), 5.13-$ $5.08(\mathrm{~m}, 1 \mathrm{H}), 3.72(\mathrm{~s}, 3 \mathrm{H}), 2.72(\mathrm{~d}, J=7.7 \mathrm{~Hz}, 1 \mathrm{H}), 2.62(\mathrm{dd}, J=8.7,13.6 \mathrm{~Hz}, 1 \mathrm{H}), 2.30(\mathrm{~d}$, $J=10.7 \mathrm{~Hz}, 2 \mathrm{H}), 2.20(\mathrm{~s}, 1 \mathrm{H}), 2.17(\mathrm{~s}, 5 \mathrm{H}), 1.79-1.52(\mathrm{~m}, 4 \mathrm{H}), 1.45(\mathrm{~s}, 3 \mathrm{H}), 1.08(\mathrm{~s}$, $3 \mathrm{H}) .{ }^{13} \mathrm{C} \mathrm{NMR}\left(126 \mathrm{MHz}, \mathrm{CDCl}_{3}\right) \delta 202.27,193.59,171.80,171.60,170.41,161.34$, 131.84, 126.60, 116.09, 77.44, 75.25, 65.01, 53.45, 52.21, 49.43, 42.25, 38.48, 37.94, 35.71, 30.88, 20.85, 18.46, 17.06, 16.23. HRMS ( $\mathrm{m} / \mathrm{z}): \mathrm{M}-\mathrm{H}]$ calcd for $\mathrm{C}_{26} \mathrm{H}_{29} \mathrm{O}_{9}, 485.1812$; found 485.1783 . HPLC $t_{\mathrm{R}}=4.624 \mathrm{~min}$; purity $=95.63 \%$.

5.4.8. (2S,4aR,6aR,7R,9S,10aS,10bR)-methyl 9-acetoxy-2-(3carbamoylbenzoyl)-6a,10b-dimethyl-4,10-dioxododecahydro- $1 \mathrm{H}$ benzo[f $]$ isochromene-7-carboxylate (19)-Compound 19 was synthesized from compound $\mathbf{1 1}$ using the general procedure and 3-aminocarbonylphenylboronic acid to afford $0.062 \mathrm{~g}(37.8 \%)$ isolated as a white solid, $\mathrm{mp}=148-152{ }^{\circ} \mathrm{C} .{ }^{1} \mathrm{H}$ NMR $\left(500 \mathrm{MHz}, \mathrm{CDCl}_{3}\right)$ $\delta 8.30(\mathrm{~s}, 1 \mathrm{H}), 8.07(\mathrm{~d}, J=7.8 \mathrm{~Hz}, 1 \mathrm{H}), 8.02(\mathrm{~d}, J=7.9 \mathrm{~Hz}, 1 \mathrm{H}), 7.58(\mathrm{t}, J=7.8 \mathrm{~Hz}, 1 \mathrm{H})$, $6.52-6.31(\mathrm{~m}, 1 \mathrm{H}), 5.88(\mathrm{t}, J=8.4 \mathrm{~Hz}, 1 \mathrm{H}), 5.84-5.65(\mathrm{~m}, 1 \mathrm{H}), 5.18-5.11(\mathrm{~m}, 1 \mathrm{H}), 3.72$ (s, 3H), $2.82-2.73(\mathrm{~m}, 1 \mathrm{H}), 2.65(\mathrm{dd}, J=8.4,13.6 \mathrm{~Hz}, 1 \mathrm{H}), 2.28(\mathrm{dd}, J=7.3,13.3 \mathrm{~Hz}, 3 \mathrm{H})$, $2.20-2.09(\mathrm{~m}, 5 \mathrm{H}), 1.78(\mathrm{~d}, J=13.0 \mathrm{~Hz}, 1 \mathrm{H}), 1.75-1.54(\mathrm{~m}, 3 \mathrm{H}), 1.47(\mathrm{~s}, 3 \mathrm{H}), 1.09(\mathrm{~s}$, $3 \mathrm{H}) .{ }^{13} \mathrm{C}$ NMR $\left(126 \mathrm{MHz}, \mathrm{CDCl}_{3}\right) \delta 202.32,194.95,171.81,170.95,170.22,168.05$, $134.59,133.96,133.38,132.26,129.75,127.79,75.66,75.18,64.74,53.40,52.20,49.71$, 42.24, 38.11, 37.91, 35.78, 30.90, 20.82, 18.49, 16.87, 16.27. HRMS ( $\mathrm{m} / \mathrm{z}):[\mathrm{M}+\mathrm{Na}] \mathrm{calcd}$ for $\mathrm{C}_{27} \mathrm{H}_{31} \mathrm{NO}_{9} \mathrm{Na}$, 536.1897; found 536.1901. HPLC $t_{\mathrm{R}}=3.465 \mathrm{~min}$; purity $=96.22 \%$ using $40 \% \mathrm{CH}_{3} \mathrm{CN}: 60 \% \mathrm{H}_{2} \mathrm{O}$ as the mobile phase.

5.4.9. (2S,4a $R, 6 \mathrm{a} R, 7 R, 9 S, 10 \mathrm{a} S, 10 \mathrm{~b} R$ )-methyl 9-acetoxy-2-(3-cyanobenzoyl)-6a, 10b-dimethyl-4,10-dioxododecahydro-1 $\mathrm{H}$-benzo[ $f$ ] isochromene-7-carboxylate (20)—Compound $\mathbf{2 0}$ was synthesized from compound $\mathbf{1 1}$ using the general procedure and 3-cyanophenylboronic acid to afford $0.055 \mathrm{~g}(43.9 \%)$ isolated as a white solid, $\mathrm{mp}=124-$ $127{ }^{\circ} \mathrm{C} .{ }^{1} \mathrm{H}$ NMR $\left(500 \mathrm{MHz}, \mathrm{CDCl}_{3}\right) \delta 8.25(\mathrm{t}, J=1.4 \mathrm{~Hz}, 1 \mathrm{H}), 8.18-8.14(\mathrm{~m}, 1 \mathrm{H}), 7.92-$ $7.88(\mathrm{~m}, 1 \mathrm{H}), 7.66(\mathrm{t}, J=7.8 \mathrm{~Hz}, 1 \mathrm{H}), 5.79(\mathrm{t}, J=8.3 \mathrm{~Hz}, 1 \mathrm{H}), 5.18-5.10(\mathrm{~m}, 1 \mathrm{H}), 3.72(\mathrm{~s}$, $3 \mathrm{H}), 2.80-2.71(\mathrm{~m}, 1 \mathrm{H}), 2.58(\mathrm{dd}, J=7.9,13.7 \mathrm{~Hz}, 1 \mathrm{H}), 2.35-2.26(\mathrm{~m}, 2 \mathrm{H}), 2.21(\mathrm{~s}, 1 \mathrm{H})$, $2.20-2.08(\mathrm{~m}, 5 \mathrm{H}), 1.82-1.52(\mathrm{~m}, 4 \mathrm{H}), 1.48(\mathrm{~s}, 3 \mathrm{H}), 1.10(\mathrm{~s}, 3 \mathrm{H}) .{ }^{13} \mathrm{C} \mathrm{NMR}(126 \mathrm{MHz}$, $\left.\mathrm{CDCl}_{3}\right) \delta 202.11,193.43,171.71,170.42,170.09,137.18,134.85,133.13,132.96,130.28$, 117.76, 113.99, 75.65, 75.05, 64.78, 53.49, 52.22, 50.01, 42.18, 37.90, 37.64, 35.72, 30.88, 20.80, 18.41, 16.77, 16.30. HRMS ( $\mathrm{m} / \mathrm{z})$ : [M-H] calcd for $\mathrm{C}_{27} \mathrm{H}_{28} \mathrm{NO}_{8}, 494.1815$; found 494.1806. HPLC $t_{\mathrm{R}}=6.510 \mathrm{~min}$; purity $=95.94 \%$.

5.4.10. (2S,4aR,6aR,7R,9S,10aS,10bR)-methyl 9-acetoxy-6a,10b-dimethyl-4,10dioxo-2-(3-(trifluoromethoxy)benzoyl)dodecahydro- $1 \mathrm{H}$ benzo[f]isochromene-7-carboxylate (21)-Compound 21 was synthesized from compound $\mathbf{1 1}$ using the general procedure and 3-(trifluoromethoxy)-phenylboronic acid to afford $0.038 \mathrm{~g}(24.3 \%)$ isolated as a white solid, $\mathrm{mp}=92-94{ }^{\circ} \mathrm{C} .{ }^{1} \mathrm{H}$ NMR $(500 \mathrm{MHz}$, $\left.\mathrm{CDCl}_{3}\right) \delta 7.86-7.80(\mathrm{~m}, 2 \mathrm{H}), 7.56(\mathrm{t}, J=8.0 \mathrm{~Hz}, 1 \mathrm{H}), 7.48(\mathrm{~d}, J=7.2 \mathrm{~Hz}, 1 \mathrm{H}), 5.81$ (t, $J=$ $8.3 \mathrm{~Hz}, 1 \mathrm{H}), 5.16-5.09(\mathrm{~m}, 1 \mathrm{H}), 3.72(\mathrm{~s}, 3 \mathrm{H}), 2.78-2.69(\mathrm{~m}, 1 \mathrm{H}), 2.62(\mathrm{dd}, J=8.3,13.6$ $\mathrm{Hz}, 1 \mathrm{H}), 2.29$ (dd, $J=7.2,13.5 \mathrm{~Hz}, 2 \mathrm{H}), 2.19(\mathrm{~s}, 1 \mathrm{H}), 2.18-2.09$ (m, 5H), 1.77 (d, $J=13.2$ 
$\mathrm{Hz}, 1 \mathrm{H}), 1.71-1.53(\mathrm{~m}, 3 \mathrm{H}), 1.47(\mathrm{~s}, 3 \mathrm{H}), 1.09(\mathrm{~s}, 3 \mathrm{H}) .{ }^{13} \mathrm{C} \mathrm{NMR}\left(126 \mathrm{MHz}, \mathrm{CDCl}_{3}\right) \delta$ $202.15,193.97,171.75,170.72,170.07,150.00\left(\mathrm{q}^{3} J_{\mathrm{CF}}=1.97\right), 135.62,130.91,127.43$, $126.77,121.56,120.56$ (q $\left.J_{\mathrm{CF}}=258.18\right), 75.62,75.06,64.91,53.48,52.21,49.77,42.19$, 38.03, 37.91, 35.76, 30.89, 20.79, 18.44, 16.88, 16.27. HRMS $(\mathrm{m} / \mathrm{z})$ : $[\mathrm{M}+\mathrm{Na}]$ calcd for $\mathrm{C}_{27} \mathrm{H}_{29} \mathrm{~F}_{3} \mathrm{O}_{9} \mathrm{Na}$, 577.1661; found 577.1621. HPLC $t_{\mathrm{R}}=15.925 \mathrm{~min}$; purity $=97.74 \%$.

5.4.11. (2S,4a $R, 6 \mathrm{a} R, 7 R, 9 S, 10 \mathrm{a} S, 10 \mathrm{~b} R)$-methyl 9-acetoxy-6a,10b-dimethyl-4,10dioxo-2-(3-(trifluoromethyl)benzoyl)dodecahydro-1 $\mathrm{H}$-benzo[f]isochromene-7carboxylate (22)-Compound 22 was synthesized from compound $\mathbf{1 1}$ using the general procedure and 3-(trifluoromethyl)phenylboronic acid to afford $0.044 \mathrm{~g} \mathrm{(38.8 \% )} \mathrm{isolated} \mathrm{as}$ an off-white solid, $\mathrm{mp}=94-97^{\circ} \mathrm{C} .{ }^{1} \mathrm{H}$ NMR $\left(500 \mathrm{MHz}, \mathrm{CDCl}_{3}\right) \delta 8.23(\mathrm{~s}, 1 \mathrm{H}), 8.10(\mathrm{~d}, J$ $=7.9 \mathrm{~Hz}, 1 \mathrm{H}), 7.88(\mathrm{~d}, J=7.8 \mathrm{~Hz}, 1 \mathrm{H}), 7.66(\mathrm{t}, J=7.8 \mathrm{~Hz}, 1 \mathrm{H}), 5.84(\mathrm{t}, J=8.3 \mathrm{~Hz}, 1 \mathrm{H})$, $5.16-5.10(\mathrm{~m}, 1 \mathrm{H}), 3.72(\mathrm{~s}, 3 \mathrm{H}), 2.79-2.70(\mathrm{~m}, 1 \mathrm{H}), 2.61(\mathrm{dd}, J=8.2,13.6 \mathrm{~Hz}, 1 \mathrm{H}), 2.29$ (dd, $J=7.5,13.5 \mathrm{~Hz}, 2 \mathrm{H}), 2.20(\mathrm{~s}, 1 \mathrm{H}), 2.19-2.08(\mathrm{~m}, 5 \mathrm{H}), 1.77$ (d, $J=13.2 \mathrm{~Hz}, 1 \mathrm{H}), 1.75$ $-1.53(\mathrm{~m}, 3 \mathrm{H}), 1.48(\mathrm{~s}, 3 \mathrm{H}), 1.09(\mathrm{~s}, 3 \mathrm{H}) .{ }^{13} \mathrm{C}$ NMR $\left(126 \mathrm{MHz}, \mathrm{CDCl}_{3}\right) \delta 202.15,194.16$, $171.74,170.66,170.08,134.49,132.33,132.05\left(\mathrm{q},{ }^{2} J_{\mathrm{CF}}=33.11 \mathrm{~Hz}\right), 130.87\left(\mathrm{q},{ }^{3} J_{\mathrm{CF}}=3.41\right.$ $\mathrm{Hz}), 129.97,126.18\left(\mathrm{q},{ }^{3} J_{\mathrm{CF}}=3.84 \mathrm{~Hz}\right), 123.63\left(\mathrm{q}, J_{\mathrm{CF}}=272.85 \mathrm{~Hz}\right), 75.56,75.06,64.91$, 53.49, 52.22, 49.84, 42.20, 37.92, 37.86, 35.75, 30.90, 20.80, 18.44, 16.90, 16.28. HRMS $(\mathrm{m} / \mathrm{z})$ : $[\mathrm{M}+\mathrm{Na}]$ calcd for $\mathrm{C}_{27} \mathrm{H}_{29} \mathrm{~F}_{3} \mathrm{O}_{8} \mathrm{Na}, 561.1712$; found 561.1670. HPLC $t_{\mathrm{R}}=5.799 \mathrm{~min}$; purity $=95.0 \%$ as determined using a Phenomenex Luna column $(250 \times 4.5 \mathrm{~mm}, 5 \mu \mathrm{m})$.

\subsubsection{2. (2S,4aR,6aR,7R,9S,10aS,10bR)-methyl 9-acetoxy-2-(furan-2- carbonyl)-6a,10b-dimethyl-4,10-dioxododecahydro- $1 \mathrm{H}$ -} benzo[f]isochromene-7-carboxylate (23)-Compound 23 was synthesized from compound 11 using the general procedure and 2-furanylboronic acid to afford $0.109 \mathrm{~g}$ $(84.6 \%)$ isolated as a white solid, $\mathrm{mp}=207-209^{\circ} \mathrm{C}$. HRMS $(\mathrm{m} / \mathrm{z}):[\mathrm{M}+\mathrm{H}]$ calcd for $\mathrm{C}_{24} \mathrm{H}_{29} \mathrm{O}_{9}, 461.1812$; found 461.1796 . HPLC $t_{\mathrm{R}}=13.29$ min; purity $=97.83 \%$ using $40 \%$ $\mathrm{CH}_{3} \mathrm{CN}: 60 \% \mathrm{H}_{2} \mathrm{O}$ as the mobile phase. The ${ }^{1} \mathrm{H}$ NMR and ${ }^{13} \mathrm{C}$ NMR spectra were in agreement with that previously reported. ${ }^{32}$

\subsubsection{3. $(2 S, 4 \mathrm{a} R, 6 \mathrm{a} R, 7 R, 9 S, 10 \mathrm{a} S, 10 \mathrm{~b} R)$-methyl 9-acetoxy-2-(furan-3- carbonyl)-6a,10b-dimethyl-4,10-dioxododecahydro- $1 \mathrm{H}$ - benzo[f]isochromene-7-carboxylate (24)-Compound 24 was synthesized from} compound $\mathbf{1 1}$ using the general procedure and furan-3-boronic acid to afford $0.106 \mathrm{~g}$ $(67.5 \%)$ isolated as a white solid, $\mathrm{mp}=159-161{ }^{\circ} \mathrm{C} .{ }^{1} \mathrm{H} \mathrm{NMR}\left(500 \mathrm{MHz}, \mathrm{CDCl}_{3}\right) \delta 8.20$ (dd, $J=0.8,1.3 \mathrm{~Hz}, 1 \mathrm{H}), 7.44$ (dd, $J=1.4,1.9 \mathrm{~Hz}, 1 \mathrm{H}), 6.79(\mathrm{dd}, J=0.8,1.9 \mathrm{~Hz}, 1 \mathrm{H}), 5.28$ (t, $J=8.0 \mathrm{~Hz}, 1 \mathrm{H}), 5.17-5.07(\mathrm{~m}, 1 \mathrm{H}), 3.69(\mathrm{~s}, 3 \mathrm{H}), 2.71(\mathrm{dd}, J=5.4,11.4 \mathrm{~Hz}, 1 \mathrm{H}), 2.54$ (dd, $J=7.8,13.8 \mathrm{~Hz}, 1 \mathrm{H}), 2.33-2.23(\mathrm{~m}, 2 \mathrm{H}), 2.18(\mathrm{~s}, 1 \mathrm{H}), 2.14(\mathrm{~s}, 3 \mathrm{H}), 2.10-2.01(\mathrm{~m}$, $2 \mathrm{H}), 1.79-1.70(\mathrm{~m}, 2 \mathrm{H}), 1.69-1.58(\mathrm{~m}, 1 \mathrm{H}), 1.55-1.47(\mathrm{~m}, 1 \mathrm{H}), 1.40(\mathrm{~s}, 3 \mathrm{H}), 1.06(\mathrm{~s}$, $3 \mathrm{H}) .{ }^{13} \mathrm{C}$ NMR $\left(126 \mathrm{MHz}, \mathrm{CDCl}_{3}\right) \delta 202.05,191.00,171.77,170.83,170.06,149.28$, 144.44, 124.23, 109.43, 78.51, 75.08, 64.82, 53.52, 52.19, 50.08, 42.18, 38.25, 37.92, 35.57, 30.90, 20.80, 18.40, 16.97, 16.32. HRMS (m/z): $[\mathrm{M}+\mathrm{H}]$ calcd for $\mathrm{C}_{24} \mathrm{H}_{29} \mathrm{O}_{9}, 461.1812$; found 461.1796 . HPLC $t_{\mathrm{R}}=5.105 \mathrm{~min}$; purity $=99.67 \%$.

5.4.14. (2S,4a $R, 6 \mathrm{a} R, 7 R, 9 S, 10 \mathrm{a} S, 10 \mathrm{~b} R)$-methyl 9-acetoxy-6a,10b-dimethyl-4,10dioxo-2-(thiophene-2-carbonyl)dodecahydro-1 H-benzo[f]isochromene-7carboxylate (25)-Compound $\mathbf{2 5}$ was synthesized from compound $\mathbf{1 1}$ using the general procedure and 2-thiopheneboronic acid to afford $0.036 \mathrm{~g} \mathrm{(36.4 \% )} \mathrm{isolated} \mathrm{as} \mathrm{an} \mathrm{off-white}$ solid, $\mathrm{mp}=188-190^{\circ} \mathrm{C}$. HRMS $(\mathrm{m} / \mathrm{z})$ : $[\mathrm{M}+\mathrm{Na}]$ calcd for $\mathrm{C}_{24} \mathrm{H}_{28} \mathrm{O}_{8} \mathrm{SNa}, 499.1403$; found 499.1380. HPLC $t_{\mathrm{R}}=5.733 \mathrm{~min}$; purity $=96.12 \%$. The ${ }^{1} \mathrm{H}$ NMR and ${ }^{13} \mathrm{C}$ NMR spectra were in agreement with that previously reported. ${ }^{32}$ 
5.4.15. (2S,4aR,6aR,7R,9S,10aS,10bR)-methyl 9-acetoxy-6a,10b-dimethyl-4,10dioxo-2-(thiophene-3-carbonyl)dodecahydro-1 $H$-benzo[ $f$ ]isochromene-7carboxylate (26)-Compound $\mathbf{2 6}$ was synthesized from compound $\mathbf{1 1}$ using the general procedure and 3-thiopheneboronic acid to afford $0.081 \mathrm{~g} \mathrm{(74.3 \% )} \mathrm{isolated} \mathrm{as} \mathrm{an} \mathrm{off-white}$ solid, $\mathrm{mp}=170-173{ }^{\circ} \mathrm{C} .{ }^{1} \mathrm{H}$ NMR $\left(500 \mathrm{MHz}, \mathrm{CDCl}_{3}\right) \delta 8.20(\mathrm{dd}, J=1.2,2.8 \mathrm{~Hz}, 1 \mathrm{H})$, $7.56(\mathrm{dd}, J=1.2,5.1 \mathrm{~Hz}, 1 \mathrm{H}), 7.37(\mathrm{dd}, J=2.9,5.1 \mathrm{~Hz}, 1 \mathrm{H}), 5.60(\mathrm{t}, J=8.1 \mathrm{~Hz}, 1 \mathrm{H}), 5.17-$ $5.08(\mathrm{~m}, 1 \mathrm{H}), 3.72(\mathrm{~s}, 3 \mathrm{H}), 2.78-2.67(\mathrm{~m}, 1 \mathrm{H}), 2.61(\mathrm{dd}, J=8.3,13.7 \mathrm{~Hz}, 1 \mathrm{H}), 2.29(\mathrm{dd}, J=$ $7.5,13.5 \mathrm{~Hz}, 2 \mathrm{H}), 2.20(\mathrm{~s}, 1 \mathrm{H}), 2.19-2.06(\mathrm{~m}, 5 \mathrm{H}), 1.71(\mathrm{ddd}, J=12.5,22.2,34.2 \mathrm{~Hz}, 3 \mathrm{H})$, $1.59-1.49(\mathrm{~m}, 1 \mathrm{H}), 1.45(\mathrm{~s}, 3 \mathrm{H}), 1.08(\mathrm{~s}, 3 \mathrm{H}) .{ }^{13} \mathrm{C} \mathrm{NMR}\left(126 \mathrm{MHz}, \mathrm{CDCl}_{3}\right) \delta 202.17$, $189.63,171.78,171.01,170.06,138.44,134.68,127.63,127.21,77.09,75.08,64.96,53.49$, 52.19, 49.71, 42.20, 38.30, 37.92, 35.69, 30.90, 20.81, 18.44, 17.05, 16.27. HRMS (m/z):

$[\mathrm{M}+\mathrm{Na}]$ calcd for $\mathrm{C}_{24} \mathrm{H}_{28} \mathrm{O}_{8} \mathrm{SNa}$, 499.1403; found 499.1393. HPLC $t_{\mathrm{R}}=5.657 \mathrm{~min}$; purity $=99.78 \%$.

\subsubsection{6. (2S,4aR,6aR,7R,9S,10aS,10bR)-methyl 9-acetoxy-2-(benzofuran-2- carbonyl)-6a,10b-dimethyl-4,10-dioxododecahydro-1 $\mathrm{H}$ - \\ benzo[f]isochromene-7-carboxylate (27)—Compound 27 was synthesized from} compound 11 using the general procedure and 2-benzofuranylboronic acid to afford $0.090 \mathrm{~g}$ $(77.2 \%)$ isolated as a white solid, $\mathrm{mp}=228-232{ }^{\circ} \mathrm{C} .{ }^{1} \mathrm{H} \mathrm{NMR}\left(500 \mathrm{MHz}, \mathrm{CDCl}_{3}\right) \delta 7.74$ $(\mathrm{d}, J=7.8 \mathrm{~Hz}, 1 \mathrm{H}), 7.71(\mathrm{~d}, J=0.9 \mathrm{~Hz}, 1 \mathrm{H}), 7.60(\mathrm{dd}, J=0.8,8.5 \mathrm{~Hz}, 1 \mathrm{H}), 7.55-7.50(\mathrm{~m}$, $1 \mathrm{H}), 7.38-7.31(\mathrm{~m}, 1 \mathrm{H}), 5.75(\mathrm{t}, J=8.3 \mathrm{~Hz}, 1 \mathrm{H}), 5.16-5.08(\mathrm{~m}, 1 \mathrm{H}), 3.72(\mathrm{~s}, 3 \mathrm{H}), 2.77-$ $2.67(\mathrm{~m}, 2 \mathrm{H}), 2.29(\mathrm{dd}, J=7.5,13.5 \mathrm{~Hz}, 2 \mathrm{H}), 2.25-2.18(\mathrm{~m}, 2 \mathrm{H}), 2.18-2.11(\mathrm{~m}, 4 \mathrm{H}), 1.81$ $-1.60(\mathrm{~m}, 4 \mathrm{H}), 1.48(\mathrm{~s}, 3 \mathrm{H}), 1.10(\mathrm{~s}, 3 \mathrm{H}) .{ }^{13} \mathrm{C}$ NMR $\left(126 \mathrm{MHz}, \mathrm{CDCl}_{3}\right) \delta 202.15,186.33$, $171.78,170.86,170.04,156.20,149.86,129.49,126.98,124.56,123.93,116.49,112.90$, 76.49, 75.07, 64.86, 53.49, 52.20, 49.92, 42.22, 38.22, 37.95, 35.77, 30.92, 20.80, 18.45, 16.78, 16.29. HRMS $(\mathrm{m} / \mathrm{z})$ : [M+Na] calcd for $\mathrm{C}_{28} \mathrm{H}_{30} \mathrm{O} 9 \mathrm{Na}, 533.1788$; found 533.1797. HPLC $t_{\mathrm{R}}=7.558 \mathrm{~min}$; purity $=99.33 \%$.

\subsubsection{7. (2S,4aR,6a R,7R,9S,10aS,10bR)-methyl 9-acetoxy-2-} (benzo[b]thiophene-2-carbonyl)-6a,10bdimethyl-4,10-dioxododecahydro- $1 \mathrm{H}$ benzo[ $f]$ isochromene-7-carboxylate (28)—Compound $\mathbf{2 8}$ was synthesized from compound $\mathbf{1 1}$ using the general procedure and thianaphthene-2-boronic acid to afford 0.095 $\mathrm{g}(78.8 \%)$ isolated as a white solid, $\mathrm{mp}=127-130{ }^{\circ} \mathrm{C} .{ }^{1} \mathrm{H} \mathrm{NMR}\left(500 \mathrm{MHz}, \mathrm{CDCl}_{3}\right) \delta 8.10$ (s, 1H), $7.93(\mathrm{~d}, J=8.0 \mathrm{~Hz}, 1 \mathrm{H}), 7.88(\mathrm{~d}, J=8.1 \mathrm{~Hz}, 1 \mathrm{H}), 7.54-7.46(\mathrm{~m}, 1 \mathrm{H}), 7.46-7.40$ $(\mathrm{m}, 1 \mathrm{H}), 5.74(\mathrm{t}, J=8.2 \mathrm{~Hz}, 1 \mathrm{H}), 5.19-5.09(\mathrm{~m}, 1 \mathrm{H}), 3.72(\mathrm{~s}, 3 \mathrm{H}), 2.79-2.71(\mathrm{~m}, 1 \mathrm{H})$, 2.67 (dd, $J=8.1,13.7 \mathrm{~Hz}, 1 \mathrm{H}), 2.34-2.25(\mathrm{~m}, 2 \mathrm{H}), 2.25-2.18(\mathrm{~m}, 2 \mathrm{H}), 2.17-2.08(\mathrm{~m}$, $4 \mathrm{H}), 1.85-1.73(\mathrm{~m}, 2 \mathrm{H}), 1.73-1.63(\mathrm{~m}, 1 \mathrm{H}), 1.63-1.53(\mathrm{~m}, 1 \mathrm{H}), 1.48(\mathrm{~s}, 3 \mathrm{H}), 1.09(\mathrm{~s}$, $3 \mathrm{H}) .{ }^{13} \mathrm{C}$ NMR $\left(126 \mathrm{MHz}, \mathrm{CDCl}_{3}\right) \delta 202.22,190.04,171.79,170.84,170.01,143.20$, $139.72,139.13,131.67,128.45,126.81,125.56,123.11,76.90,75.08,64.83,53.46,52.19$, $49.81,42.21,38.59,37.90,35.75,30.91,20.79,18.44,16.98,16.29$. HRMS ( $m / z):[\mathrm{M}+\mathrm{Na}]$ calcd for $\mathrm{C}_{28} \mathrm{H}_{30} \mathrm{O}_{8} \mathrm{SNa}, 549.1559$; found 549.1573. HPLC $t_{\mathrm{R}}=9.577$ min; purity $=$ 98.44\%.

\subsubsection{8. $(2 S, 4 \mathrm{a} R, 6 \mathrm{a} R, 7 R, 9 S, 10 \mathrm{a} S, 10 \mathrm{~b} R)$-methyl 9-acetoxy-2-} (benzo[b]thiophene-3-carbonyl)-6a,10bdimethyl-4,10-dioxododecahydro- $1 \mathrm{H}$ benzo[ $f]$ isochromene-7-carboxylate (29)—Compound 29 was synthesized from compound $\mathbf{1 1}$ using the general procedure and 1-benzothiophen-3-ylboronic acid to afford $0.065 \mathrm{~g}(23.3 \%)$ isolated as an off-white solid, $\mathrm{mp}=133-136{ }^{\circ} \mathrm{C} .{ }^{1} \mathrm{H}$ NMR $(500 \mathrm{MHz}$, $\left.\mathrm{CDCl}_{3}\right) \delta 8.72(\mathrm{~d}, J=7.9 \mathrm{~Hz}, 1 \mathrm{H}), 8.43(\mathrm{~s}, 1 \mathrm{H}), 7.89(\mathrm{~d}, J=7.9 \mathrm{~Hz}, 1 \mathrm{H}), 7.56-7.50(\mathrm{~m}$, $1 \mathrm{H}), 7.46(\mathrm{dd}, J=4.1,11.1 \mathrm{~Hz}, 1 \mathrm{H}), 5.77(\mathrm{t}, J=8.2 \mathrm{~Hz}, 1 \mathrm{H}), 5.18-5.08(\mathrm{~m}, 1 \mathrm{H}), 3.72(\mathrm{~s}$, $3 \mathrm{H}), 2.77-2.70(\mathrm{~m}, 1 \mathrm{H}), 2.65(\mathrm{dd}, J=8.3,13.7 \mathrm{~Hz}, 1 \mathrm{H}), 2.29(\mathrm{dd}, J=7.2,13.5 \mathrm{~Hz}, 2 \mathrm{H})$, $2.26-2.18(\mathrm{~m}, 2 \mathrm{H}), 2.13(\mathrm{~d}, J=16.9 \mathrm{~Hz}, 4 \mathrm{H}), 1.84-1.53(\mathrm{~m}, 4 \mathrm{H}), 1.47(\mathrm{~s}, 3 \mathrm{H}), 1.09(\mathrm{~s}$, 
3H). ${ }^{13} \mathrm{C}$ NMR $\left(126 \mathrm{MHz}, \mathrm{CDCl}_{3}\right) \delta 202.27,190.09,171.80,171.13,170.04,139.79$, $139.45,136.99,131.61,126.46,126.16,125.67,122.57,76.76,75.12,64.94,53.50,52.19$, $49.68,42.23,38.51,37.97,35.68,30.91,20.79,18.46,17.06,16.26$. HRMS $(\mathrm{m} / \mathrm{z}):[\mathrm{M}+\mathrm{H}]$ calcd for $\mathrm{C}_{28} \mathrm{H}_{31} \mathrm{O}_{8} \mathrm{~S}, 527.1740$; found 527.1742. HPLC $t_{\mathrm{R}}=6.64 \mathrm{~min}$; purity $=96.84 \%$.

5.4.19. (2S,4a $R, 6 \mathrm{a} R, 7 R, 9 S, 10 \mathrm{a} S, 10 \mathrm{~b} R)$-methyl 9-acetoxy-2-((Z)-but-2-enoyl)-6a, 10b-dimethyl-4,10-dioxododecahydro-1 $H$-benzo[ $f$ ] isochromene-7-carboxylate (30)-Compound $\mathbf{3 0}$ was synthesized from compound $\mathbf{1 1}$ using the general procedure and cis-1-propen-1-ylboronic acid to afford $0.195 \mathrm{~g}(72.7 \%)$ isolated as a white solid, $\mathrm{mp}=153$ $-155^{\circ} \mathrm{C} .{ }^{1} \mathrm{H}$ NMR $\left(500 \mathrm{MHz}, \mathrm{CDCl}_{3}\right) \delta 6.48(\mathrm{dq}, J=7.3,11.4 \mathrm{~Hz}, 1 \mathrm{H}), 6.33(\mathrm{dd}, J=1.7$, $11.4 \mathrm{~Hz}, 1 \mathrm{H}), 5.19-5.11(\mathrm{~m}, 1 \mathrm{H}), 4.92(\mathrm{dd}, J=7.4,9.3 \mathrm{~Hz}, 1 \mathrm{H}), 3.72(\mathrm{~s}, 3 \mathrm{H}), 2.73(\mathrm{dd}, J=$ $5.8,11.1 \mathrm{~Hz}, 1 \mathrm{H}), 2.52(\mathrm{dd}, J=7.4,13.7 \mathrm{~Hz}, 1 \mathrm{H}), 2.33-2.25(\mathrm{~m}, 2 \mathrm{H}), 2.17(\mathrm{dd}, J=2.0,7.0$ $\mathrm{Hz}, 7 \mathrm{H}), 2.10(\mathrm{dd}, J=3.4,14.3 \mathrm{~Hz}, 1 \mathrm{H}), 2.00(\mathrm{dd}, J=3.2,11.8 \mathrm{~Hz}, 1 \mathrm{H}), 1.76(\mathrm{dd}, J=3.3$, $13.3 \mathrm{~Hz}, 1 \mathrm{H}), 1.65$ (dd, $J=12.6,27.3 \mathrm{~Hz}, 1 \mathrm{H}), 1.59-1.48(\mathrm{~m}, 2 \mathrm{H}), 1.38$ (s, $3 \mathrm{H}), 1.08$ (s, $3 \mathrm{H}) .{ }^{13} \mathrm{C} \mathrm{NMR}\left(126 \mathrm{MHz}, \mathrm{CDCl}_{3}\right) \delta 201.98,196.49,171.76,170.83,170.10,149.06$, $122.82,79.95,75.10,64.78,53.60,52.20,50.37,42.21,38.05,37.94,35.56,30.91,20.81$, 18.40, 16.76, 16.43, 16.35. HRMS (m/z): [M+Na] calcd for $\mathrm{C}_{23} \mathrm{H}_{30} \mathrm{O}_{8} \mathrm{Na}, 457.1838$; found 457.1859. $\mathrm{HPLC} t_{\mathrm{R}}=15.253 \mathrm{~min}$; purity $=95.43 \%$ using $40 \% \mathrm{CH}_{3} \mathrm{CN}: 60 \% \mathrm{H}_{2} \mathrm{O}$ as the mobile phase.

\subsection{Preparation of $(2 S, 4 \mathrm{a} R, 6 \mathrm{a} R, 7 R, 9 S, 10 \mathrm{a} S, 10 \mathrm{~b} R)$-methyl 9-acetoxy-2-(furan-2-yl)-6a,10b- dimethyl-4,10-di-oxododecahydro-1 $H$-benzo[ $f$ ]isochromene-7-carboxylate (31)}

Alkene $30(0.108 \mathrm{~g}, 0.249 \mathrm{mmol})$ was dissolved in bromobenzene $(15 \mathrm{~mL})$ followed by the addition of selenium (IV) oxide $(0.083 \mathrm{~g}, 0.746 \mathrm{mmol})$. Reaction mixture was heated at $160^{\circ} \mathrm{C}$ and monitored by TLC. The solvent was evaporated in vacuo and the resulting residue purified by flash column chromatography on silica gel using mixtures of EtOAc/nhexanes and triturated in EtOAc/ $n$-hexanes to yield $0.195 \mathrm{~g}(18.1 \%)$ of $\mathbf{3 1}$ as a white solid, mp $198-200{ }^{\circ} \mathrm{C} ;{ }^{1} \mathrm{H}$ NMR $\left(500 \mathrm{MHz}, \mathrm{CDCl}_{3}\right) \delta 7.39(\mathrm{dd}, J=0.8,1.7 \mathrm{~Hz}, 1 \mathrm{H}), 6.36-6.31$ $(\mathrm{m}, 2 \mathrm{H}), 5.52(\mathrm{dd}, J=5.6,11.6 \mathrm{~Hz}, 1 \mathrm{H}), 5.18-5.11(\mathrm{~m}, 1 \mathrm{H}), 3.73(\mathrm{~s}, 3 \mathrm{H}), 2.81-2.72(\mathrm{~m}$, $1 \mathrm{H}), 2.45(\mathrm{dd}, J=5.6,13.6 \mathrm{~Hz}, 1 \mathrm{H}), 2.36-2.27(\mathrm{~m}, 2 \mathrm{H}), 2.23(\mathrm{~s}, 1 \mathrm{H}), 2.20-2.12(\mathrm{~m}, 5 \mathrm{H})$, $1.93-1.85(\mathrm{~m}, 1 \mathrm{H}), 1.83-1.76(\mathrm{~m}, 1 \mathrm{H}), 1.71-1.59(\mathrm{~m}, 2 \mathrm{H}), 1.44(\mathrm{~s}, 3 \mathrm{H}), 1.11(\mathrm{~s}$, $3 \mathrm{H}) .{ }^{13} \mathrm{C} \mathrm{NMR}\left(126 \mathrm{MHz}, \mathrm{CDCl}_{3}\right) \delta 202.17,171.79,171.07,170.20,151.41,143.38$, 110.66, 109.27, 75.27, 72.01, 64.30, 53.78, 52.21, 51.25, 42.33, 40.52, 38.36, 35.51, 30.95, 20.79, 18.36, 16.53, 15.28. HRMS ( $\mathrm{m} / \mathrm{z})$ : [M+Na] calcd for $\mathrm{C}_{23} \mathrm{H}_{28} \mathrm{O}_{8} \mathrm{Na}, 455.1682$; found, 455.1695. HPLC $t_{\mathrm{R}}=24.103 \mathrm{~min}$; purity $=97.44 \%$ using $40 \% \mathrm{CH}_{3} \mathrm{CN}: 60 \% \mathrm{H}_{2} \mathrm{O}$ as the mobile phase.

\subsection{Opioid Binding Assay. 50}

Recombinant Chinese Hamster Ovary (CHO) cells (hMOP-CHO, hDOP-CHO and hKOP$\mathrm{CHO}$ ) were produced by stable transfection with the respective human opioid receptor cDNA, and provided by Dr. Larry Toll (SRI International, CA). The cells were grown on plastic flasks in DMEM (90\%) (hDOP-CHO and hKOP-CHO) or DMEM/ F-12 (45\%/ $45 \%)$ medium (hMOP-CHO) containing 10\% FetalClone II (HyClone) and Geneticin (G-418: $0.10-0.2 \mathrm{mg} / \mathrm{ml}$ ) (Invitrogen) under $95 \%$ air $/ 5 \% \mathrm{CO}_{2}$ at $37^{\circ} \mathrm{C}$. Cell monolayers were harvested and frozen at $-80{ }^{\circ} \mathrm{C}$. The hKOP-CHO, hMOP-CHO and hDOP-CHO cells are used for opioid binding experiments. For the $\left[{ }^{35} \mathrm{~S}\right] \mathrm{GTP}-\boldsymbol{\gamma}$-S binding experiments, we use $\mathrm{hKOP}-\mathrm{CHO}$ and hMOP-CHO cells for assaying KOP and MOP receptor function. We use the NG108-15 neuroblastomaxglioma cell for the DOP $\left[{ }^{35} \mathrm{~S}\right] \mathrm{GTP}-\boldsymbol{\gamma}-\mathrm{S}$ binding assay. We used $\left[{ }^{3} \mathrm{H}\right]\left[\mathrm{D}-\mathrm{Ala}^{2}-\mathrm{MePhe}^{4}\right.$, Gly-ol $\left.{ }^{5}\right]$ enkephalin $\left(\left[{ }^{3} \mathrm{H}\right] \mathrm{DAMGO}, \mathrm{SA}=44-48 \mathrm{Ci} / \mathrm{mmol}\right)$ to label MOP, $\left[{ }^{3} \mathrm{H}\right]\left[\mathrm{D}-\mathrm{Ala}^{2}\right.$,D-Leu $\left.{ }^{5}\right]$ enkephalin $\left(\left[{ }^{3} \mathrm{H}\right] \mathrm{DADLE}, \mathrm{SA}=40-50 \mathrm{Ci} / \mathrm{mmol}\right)$ to label DOP receptors and $\left[{ }^{3} \mathrm{H}\right](-)-\mathrm{U} 69,593(\mathrm{SA}=50 \mathrm{Ci} / \mathrm{mmol})$ to label $\mathrm{KOP}$ receptor binding sites. On the day of the assay, cell pellets were thawed on ice for 15 minutes then homogenized with a 
polytron in $10 \mathrm{~mL} /$ pellet of ice-cold $10 \mathrm{mM}$ Tris- $\mathrm{HCl}$, $\mathrm{pH}$ 7.4. Membranes were then centrifuged at $30,000 \times \mathrm{g}$ for 10 minutes, resuspended in $10 \mathrm{ml} / \mathrm{pellet}$ ice-cold $10 \mathrm{mM}$ Tris$\mathrm{HCl}, \mathrm{pH} 7.4$ and again centrifuged 30,000 $\times \mathrm{g}$ for $10 \mathrm{~min}$. Membranes were then resuspended in $25^{\circ} \mathrm{C} 50 \mathrm{mMTris}-\mathrm{HCl}, \mathrm{pH} 7.4(\sim 100 \mathrm{~mL} / \mathrm{pellet} \mathrm{hMOP-CHO}, 50 \mathrm{ml} / \mathrm{pellet}$ $\mathrm{hDOP}-\mathrm{CHO}$ and $120 \mathrm{ml} /$ pellet hKOP-CHO). All assays took place in $50 \mathrm{mMTris}-\mathrm{HCl}, \mathrm{pH}$ 7.4, with a protease inhibitor cocktail [bacitracin $(100 \mu \mathrm{g} / \mathrm{mL}$, bestatin $(10 \mu \mathrm{g} / \mathrm{mL})$, leupeptin $(4 \mu \mathrm{g} / \mathrm{mL})$ and chymostatin $(2 \mu \mathrm{g} / \mathrm{mL})]$, in a final assay volume of $1.0 \mathrm{~mL}$. All drug dilution curves were made up with buffer containing $1 \mathrm{mg} / \mathrm{mL}$ BSA. Nonspecific binding was determined using $20 \mu \mathrm{M}$ levallorphan $\left(\left[{ }^{3} \mathrm{H}\right]\right.$ DAMGO and $\left.\left[{ }^{3} \mathrm{H}\right] \mathrm{DADLE}\right)$ and 1 $\mu \mathrm{M}(-)$-U69,593 (for $\left[{ }^{3} \mathrm{H}\right] \mathrm{U} 69,593$ binding). $\left[{ }^{3} \mathrm{H}\right]$ Radioligands were used at $\sim 2 \mathrm{nM}$ concentrations. Triplicate samples were filtered with Brandel Cell Harvesters (Biomedical Research \& Development Inc., Gaithersburg, MD), over Whatman GF/B filters, after a $2 \mathrm{hr}$ incubation at $25^{\circ} \mathrm{C}$. The filters were punched into 24-well plates to which was added $0.6 \mathrm{ml}$ of LSC-cocktail (Cytoscint). Samples were counted, after an overnight extraction, in a Trilux liquid scintillation counter at $44 \%$ efficiency. Opioid binding assays had $\sim 30 \mu \mathrm{g}$ protein per assay tube. Inhibition curves were generated by displacing a single concentration of radioligand by 10 concentrations of drug.

\section{7. $\left[{ }^{35} \mathrm{~S}\right] \mathrm{GTP}-\mathrm{\gamma}-\mathrm{S}$ Binding Assay}

The $\left[{ }^{35} \mathrm{~S}\right] \mathrm{GTP}-\gamma-\mathrm{S}$ assays were conducted as described elsewhere. ${ }^{50}$ In this description, buffer "A" is $50 \mathrm{mM}$ Tris- $\mathrm{HCl}$, pH 7.4, containing $100 \mathrm{mM} \mathrm{NaCl}, 10 \mathrm{mM} \mathrm{MgCl}_{2}, 1 \mathrm{mM}$ EDTA and buffer "B" is buffer A plus $1.67 \mathrm{mM}$ DTT and 0.15\% BSA. On the day of the assay, cells were thawed on ice for $15 \mathrm{~min}$ and homogenized using a polytron in $50 \mathrm{mM}$ Tris-HCl, $\mathrm{pH} 7.4$, containing $4 \mu \mathrm{g} / \mathrm{mL}$ leupeptin, $2 \mu \mathrm{g} / \mathrm{mL}$ chymostatin, $10 \mu \mathrm{g} / \mathrm{mL}$ bestatin and $100 \mu \mathrm{g} / \mathrm{mL}$ bacitracin. The homogenate was centrifuged at $30,000 \times \mathrm{g}$ for $10 \mathrm{~min}$ at 4 ${ }^{\circ} \mathrm{C}$, and the supernatant discarded. The membrane pellets were resuspended in buffer B and used for $\left[{ }^{35} \mathrm{~S}\right] \mathrm{GTP}-\boldsymbol{\gamma}$-S binding assays. $\left[{ }^{35} \mathrm{~S}\right] \mathrm{GTP}-\boldsymbol{\gamma}$-S binding was determined as described previously. Briefly, test tubes received the following additions: $50 \mu \mathrm{L}$ buffer A plus $0.1 \%$ BSA, $50 \mu \mathrm{L}$ GDP in buffer A/0.1\% BSA (final concentration $=40 \mu \mathrm{M}$ ), $50 \mu \mathrm{L}$ drug in buffer A/0.1\% BSA, $50 \mu \mathrm{L}\left[{ }^{35} \mathrm{~S}\right] \mathrm{GTP}-\gamma-\mathrm{S}$ in buffer A/0.1\% BSA (final concentration $=50$ $\mathrm{pM}$ ), and $300 \mu \mathrm{L}$ of cell membranes ( $50 \mu \mathrm{g}$ of protein) in buffer B. The final concentrations of reagents in the $\left[{ }^{35} \mathrm{~S}\right] \mathrm{GTP}-\gamma$-S binding assays were: $50 \mathrm{mM}$ Tris-HCl, $\mathrm{pH} 7.4$, containing $100 \mathrm{mM} \mathrm{NaCl}, 10 \mathrm{mM} \mathrm{MgCl} 2,1 \mathrm{mM}$ EDTA, $1 \mathrm{mM}$ DTT, $40 \mu \mathrm{M}$ GDP and 0.1\% BSA. Incubations proceeded for $3 \mathrm{hr}$ at $25^{\circ} \mathrm{C}$. Nonspecific binding was determined using GTP- $\gamma$ $\mathrm{S}(40 \mu \mathrm{M})$. Bound and free $\left[{ }^{35} \mathrm{~S}\right] \mathrm{GTP}-\gamma-\mathrm{S}$ were separated by vacuum filtration (Brandel) through GF/B filters. The filters were punched into 24-well plates to which was added 0.6 $\mathrm{mL}$ LSC-cocktail (Cytoscint). Samples were counted, after an overnight extraction, in a Trilux liquid scintillation counter at $27 \%$ efficiency.

\subsection{Fluorescent $\mathrm{Ca}^{2+}$ Mobilization Assay. ${ }^{51}$}

All cells were maintained in F-12 nutrient medium (Ham), supplemented with $10 \%$ fetal bovine serum (FBS), $1 \%$ penicillin and streptomycin (p/s), and $0.2 \%$ normocin. Cell culture supplies were from Invitrogen (Carlsbad, CA) unless otherwise specified. CHO cells stably expressing KOP R-Gaq 16 were removed from their flasks using Versene and quenched with the Ham media, centrifuged and re-suspended in media. Cells were counted with a Cellometer Auto T4 (Nexcelom Bioscience, Lawrence, MA) and 30,000 cells were transferred to each well of a black Costar 96-well optical bottom plate (Corning Corporation, Corning, NY). Each plate was incubated at $37{ }^{\circ} \mathrm{C}$ overnight to confluence. The culture media was removed from the plates and cells were subsequently loaded with a fluorescent calcium probe (Calcium 5 dye, Molecular Devices, Sunnyvale, CA) in an HBSSbased buffer containing $20 \mathrm{mM}$ HEPES, $0.25 \% \mathrm{BSA}, 1 \%$ DMSO, and $10 \mu$ Mprobenecid (Sigma) in a total volume of $225 \mu \mathrm{L}$. Cells were incubated at $37^{\circ} \mathrm{C}$ for $1 \mathrm{~h}$ and then 
stimulated with DAMGO, U69,593 or test compounds at various concentrations using a Flexstation 3 plate-reader, which automatically added $25 \mu \mathrm{L}$ of the compounds at $10 \mathrm{X}$ concentration to each well after reading baseline values for $\sim 17 \mathrm{sec}$. Agonist-mediated change in fluorescence ( $485 \mathrm{~nm}$ excitation, $525 \mathrm{~nm}$ emission) was monitored in each well at $1.52 \mathrm{sec}$ intervals for $60 \mathrm{sec}$ and reported for each well. Data were collected using Softmax version 4.8 (MDS Analytical Technologies) and analyzed using Prism software (GraphPad, La Jolla, CA). Nonlinear regression analysis was performed to fit data and obtain maximum response max), $\mathrm{EC}_{50}$, correlation coefficient $\left(r^{2}\right)$ and other parameters. All experiments were performed at least 3 times to ensure reproducibility and data reported as mean \pm standard error, unless noted otherwise.

\subsection{Neuroendocrine biomarker assay. ${ }^{45}$}

Chair-trained male rhesus monkeys (Macaca mulatta) were tested after extensive prior exposure to the experimental situation. Approximately $15 \mathrm{~min}$ following catheter placement, two baseline blood samples of approximately $2 \mathrm{~mL}$ were collected, $5 \mathrm{~min}$ apart from each other (defined as -10 and -5 min, relative to the onset of dosing), and kept at room temperature until the time of spinning $\left(3000 \mathrm{rpm}\right.$ at $\left.4{ }^{\circ} \mathrm{C}\right)$ and serum separation.

Experiments were carried out with a cumulative dosing procedure, where doses of $\mathbf{1}$ or $\mathbf{3}$ were administered i.v. in increasing $0.5 \log$ unit steps, every $20 \mathrm{~min}$, and a blood sample was taken $15 \mathrm{~min}$ after each dose. Data for $\mathbf{1}$ were from a previous determination under identical experimental conditions. ${ }^{45}$ Serum samples were kept at $-40{ }^{\circ} \mathrm{C}$ until the time of analysis, typically within 2 weeks of collection. Samples were analyzed in duplicate with a standard human prolactin immunoradiometric kit (Siemens Medical Solutions Diagnostics, Los Angeles CA), following manufacturer's instructions. Procedures were reviewed and approved by the Rockefeller University Animal Care and Use Committee, in accordance with the Guide on the Care and Use of Animals (National Academy Press, 1996). Data are presented graphically as $\mathrm{ng} / \mathrm{ml}$ (i.e., drug effect - mean pre-injection baseline per subject). Linear regression analyses were calculated from mean dose-effect curve points spanning the $\mathrm{ED}_{50}$ point.

\section{Supplementary Material}

Refer to Web version on PubMed Central for supplementary material.

\section{Acknowledgments}

The authors thank the National Institute on Drug Abuse (DA018151 to TEP, DA05130 to MJK, and DA011113 to ERB) and the NIH Dynamic Aspects of Chemical Biology training grant (GM008545 to KML and KPS) for financial support of ongoing research, and the National Science Foundation (CHE-0923449) and the University of Kansas for funds to purchase the x-ray instrumentation and computers. Portions of this work were supported by the Intramural Research Program, National Institute on Drug Abuse, NIH, DHHS. The content is the sole responsibility of the authors and does not necessarily represent the official views of the National Institute on Drug Abuse, National Institutes of Health, or the National Science Foundation. The authors also thank Dr. Alfredo Ortega and Elihu Bautista for the pictures of Salvia sp.

\section{References}

1. Prevatt-Smith KM, Prisinzano TE. Nat. Prod. Rep. 2010; 27:23. [PubMed: 20024092]

2. Clement JA, Yoder BJ, Kingston DGI. Mini Rev. Org. Chem. 2004; 1:183.

3. Butler MS. Nat. Prod. Rep. 2005; 22:162. [PubMed: 15806196]

4. Roth BL, Baner K, Westkaemper R, Siebert D, Rice KC, Steinberg S, Ernsberger P, Rothman RB. Proc. Natl. Acad. Sci. USA. 2002; 99:11934. [PubMed: 12192085]

5. Valdes LJ III. J Psychoact. Drugs. 1994; 26:277.

6. Valdes LJ III, Butler WM, Hatfield GM, Paul AG, Koreeda M. J. Org. Chem. 1984; 49:4716. 
7. Siebert DJ. J Ethnopharmacol. 1994; 43:53. [PubMed: 7526076]

8. Valdes LJ 3rd, Diaz JL, Paul AG. J Ethnopharmacol. 1983; 7:287. [PubMed: 6876852]

9. Lange JE, Reed MB, Ketchie Croff JM, Clapp JD. Drug Alcohol Depend. 2008; 94:263. [PubMed: 18093751]

10. Lange JE, Daniel J, Homer K, Reed MB, Clapp JD. Drug Alcohol Depend. 2010; 108:138. [PubMed: 20031341]

11. Wang Y, Tang K, Inan S, Siebert D, Holzgrabe U, Lee DY, Huang P, Li JG, Cowan A, Liu-Chen LY. J. Pharmacol. Exp. Ther. 2005; 312:220. [PubMed: 15383632]

12. Li JG, Benovic JL, Liu-Chen LY. Mol. Pharmacol. 2000; 58:795. [PubMed: 10999950]

13. Chavkin C. Neuropsychopharmacology. 2011; 36:369. [PubMed: 21116263]

14. McCurdy, CR.; Prisinzano, TE. Burger's Medicinal Chemistry, Drug Discovery, and Development. Seventh Edition. Abraham, DJ.; Rotella, DP., editors. Vol. Vol. 8. John Wiley \& Sons, Inc.; 2010. p. 569

15. Rees, DC.; Hunter, JC. Comprehensive Medicinal Chemistry. Emmet, JC., editor. Pergamon; New York: 1990. p. 805

16. Eguchi M. Med. Res. Rev. 2004; 24:182. [PubMed: 14705168]

17. Kaczor A, Matosiuk D. Curr. Med. Chem. 2002; 9:1567. [PubMed: 12171553]

18. Kaczor A, Matosiuk D. Curr. Med. Chem. 2002; 9:1591. [PubMed: 12171554]

19. Pfeiffer A, Brantl V, Herz A, Emrich HM. Science. 1986; 233:774. [PubMed: 3016896]

20. Mello NK, Negus SS. Ann. NY Acad. Sci. 2000; 909:104. [PubMed: 10911926]

21. Negus SS. Psychopharmacology. 2004; 176:204. [PubMed: 15112031]

22. McLaughlin JP, Land BB, Li S, Pintar JE, Chavkin C. Neuropsychopharmacology. 2005; 31:787. [PubMed: 16123754]

23. Melief EJ, Miyatake M, Carroll FI, Beguin C, Carlezon WA, Cohen BM, Grimwood S, Mitch CH, Rorick-Kehn L, Chavkin C. Mol. Pharmacol. 2011; 80:920. [PubMed: 21832171]

24. Verhoest PR, Sawant Basak A, Parikh V, Hayward M, Kauffman GW, Paradis V, McHardy SF, McLean S, Grimwood S, Schmidt AW, Vanase-Frawley M, Freeman J, Van Deusen J, Cox L, Wong D, Liras S. J. Med. Chem. 2011; 54:5868. [PubMed: 21744827]

25. Mitch CH, Quimby SJ, Diaz N, Pedregal C, de la Torre MG, Jimenez A, Shi Q, Canada EJ, Kahl SD, Statnick MA, McKinzie DL, Benesh DR, Rash KS, Barth VN. Journal of Medicinal Chemistry. 2011; 54:8000. [PubMed: 21958337]

26. Frankowski KJ, Ghosh P, Setola V, Tran TB, Roth BL, Aube J. ACS Med. Chem. Lett. 2010; 1:189. [PubMed: 20729985]

27. Frankowski KJ, Hedrick MP, Gosalia P, Shi S, Whipple D, Ghosh P, Prisinzano TE, Schoenen F, Su Y, Vasile S, Sergienko E, Gray W, Hariharan S, Milan L, Heynen-Genel S, Mangravita-Novo A, Vicchiarelli M, Smith LH, Caron MG, Barak LS, Bohn LM, Chung TDY, Aubé J. ACS Chem. Neurosci. 2012; 3:221. [PubMed: 22737280]

28. Harding WW, Schmidt M, Tidgewell K, Kannan P, Holden KG, Gilmour B, Navarro H, Rothman RB, Prisinzano TE. J. Nat. Prod. 2006; 69:107. [PubMed: 16441078]

29. Simpson DS, Lovell KM, Lozama A, Han N, Day VW, Dersch CM, Rothman RB, Prisinzano TE. Org. Biomol. Chem. 2009; 7:3748. [PubMed: 19707679]

30. Miyake T, Uda K, Kinoshita M, Fujii M, Akita H. Chem. Pharm. Bull. 2008; 56:398. [PubMed: 18310958]

31. Lozama A, Prisinzano TE. Bioorg. Med. Chem. Lett. 2009; 19:5490. [PubMed: 19679471]

32. Béguin C, Duncan KK, Munro TA, Ho DM, Xu W, Liu-Chen L-Y, Carlezon WA Jr, Cohen BM. Bioorg. Med. Chem. 2009; 17:1370. [PubMed: 19147366]

33. Liebeskind LS, Srogl J. J. Am. Chem. Soc. 2000; 122:11260.

34. Prokopcová H, Kappe CO. Angew. Chem. Int. Ed. Engl. 2009; 48:2276. [PubMed: 19067446]

35. Yang H, Liebeskind LS. Org Lett. 2007; 9:2993. [PubMed: 17608484]

36. Yang H, Li H, Wittenberg R, Egi M, Huang W, Liebeskind LS. J. Am. Chem. Soc. 2007; 129:1132. [PubMed: 17263394]

37. Pace P, Spieser SAH, Summa V. Bioorg. Med. Chem. Lett. 2008; 18:3865. [PubMed: 18595690]

Bioorg Med Chem. Author manuscript; available in PMC 2013 May 01. 
38. Rao HSP, Jothilingam S. J. Org. Chem. 2003; 68:5392. [PubMed: 12816506]

39. Lozama A, Cunningham CW, Caspers MJ, Douglas JT, Dersch CM, Rothman RB, Prisinzano TE. J. Nat. Prod. 2011; 74:718. [PubMed: 21338114]

40. Wentland MP, Lou R, Ye Y, Cohen DJ, Richardson GP, Bidlack JM. Bioorg. Med. Chem. Lett. 2001; 11:623. [PubMed: 11266156]

41. Wentland MP, Lou R, Lu Q, Bu Y, VanAlstine MA, Cohen DJ, Bidlack JM. Bioorg. Med. Chem. Lett. 2009; 19:203. [PubMed: 19027293]

42. Yan F, Mosier PD, Westkaemper RB, Stewart J, Zjawiony JK, Vortherms TA, Sheffler DJ, Roth BL. Biochemistry. 2005; 44:8643. [PubMed: 15952771]

43. Scheerer JR, Lawrence JF, Wang GC, Evans DA. J. Am. Chem. Soc. 2007; 129:8968. [PubMed: 17602636]

44. Hagiwara H, Suka Y, Nojima T, Hoshi T, Suzuki T. Tetrahedron. 2009; 65:4820.

45. Butelman ER, Mandau M, Tidgewell K, Prisinzano TE, Yuferov V, Kreek MJ. J. Pharmacol. Exp. Ther. 2007; 320:300. [PubMed: 17060493]

46. Butelman ER, Harris TJ, Kreek M. Eur. J. Pharmacol. 1999; 383:305. [PubMed: 10594324]

47. Chang C, Byon W, Lu Y, Jacobsen L, Badura L, Sawant-Basak A, Miller E, Liu J, Grimwood S, Wang E, Maurer T. AAPS J. 2011; 13:565. [PubMed: 21847689]

48. Beguin C, Potuzak J, Xu W, Liu-Chen L-Y, Streicher JM, Groer CE, Bohn LM, Carlezon WA Jr, Cohen BM. Bioorg. Med. Chem. Lett. 2012; 22:1023. [PubMed: 22204910]

49. Tidgewell K, Harding WW, Schmidt M, Holden KG, Murry DJ, Prisinzano TE. Bioorg. Med. Chem. Lett. 2004; 14:5099. [PubMed: 15380207]

50. Fontana G, Savona G, Rodríguez B, Dersch CM, Rothman RB, Prisinzano TE. Tetrahedron. 2008; 64:10041. [PubMed: 20027203]

51. Holden KG, Tidgewell K, Marquam A, Rothman RB, Navarro H, Prisinzano TE. Bioorg. Med. Chem. Lett. 2007; 17:6111. [PubMed: 17904842] 

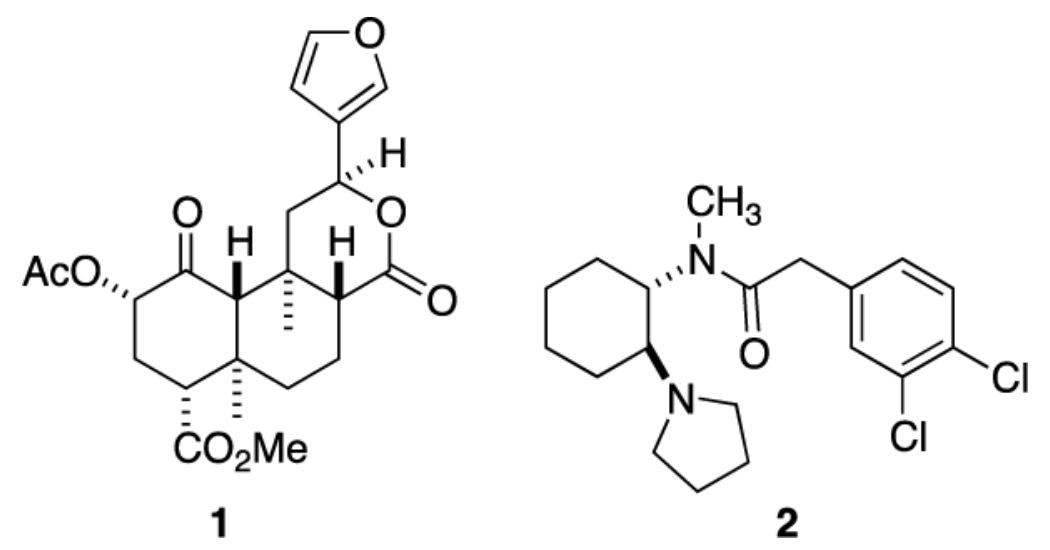

Figure 1.

Structures of salvinorin A (1) and U50,488 (2). 


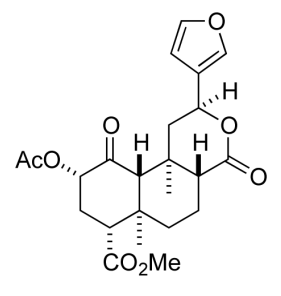

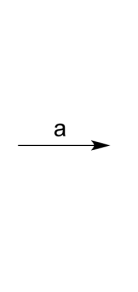

$\longrightarrow$

AcO."

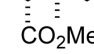

3

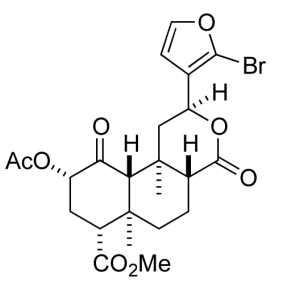

4

Scheme 1.

${ }^{a}$ Reagents and Conditions: a) 2,4,4,6-Tetrabromo-2,5-cyclohexadienone, $\mathrm{CH}_{2} \mathrm{Cl}_{2}, 130{ }^{\circ} \mathrm{C}$, 30 min MW. 

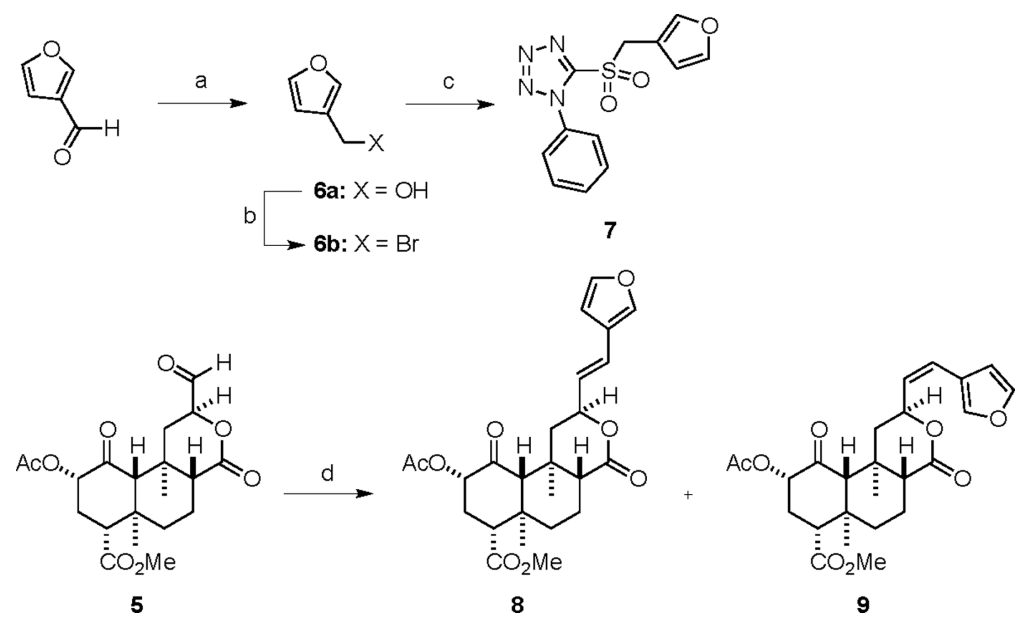

Scheme 2.

${ }^{a}$ Reagents and Conditions: a) $\mathrm{NaBH}_{4}, \mathrm{I}_{2}$, THF, $0{ }^{\circ} \mathrm{C}$; b) $\mathrm{PBr}_{3}$, THF, $0{ }^{\circ} \mathrm{C}$; c) 1-phenyl- $1 H$ tetrazole-5-thiol, $\mathrm{Et}_{3} \mathrm{~N}, \mathrm{H}_{2} \mathrm{O}_{2},\left(\mathrm{NH}_{4}\right)_{6} \mathrm{Mo}_{7} \mathrm{O}_{24} \cdot 4 \mathrm{H}_{2} \mathrm{O}, \mathrm{CH}_{2} \mathrm{Cl}_{2}$; d) 7, KHMDS, THF, $-78{ }^{\circ} \mathrm{C}$ 

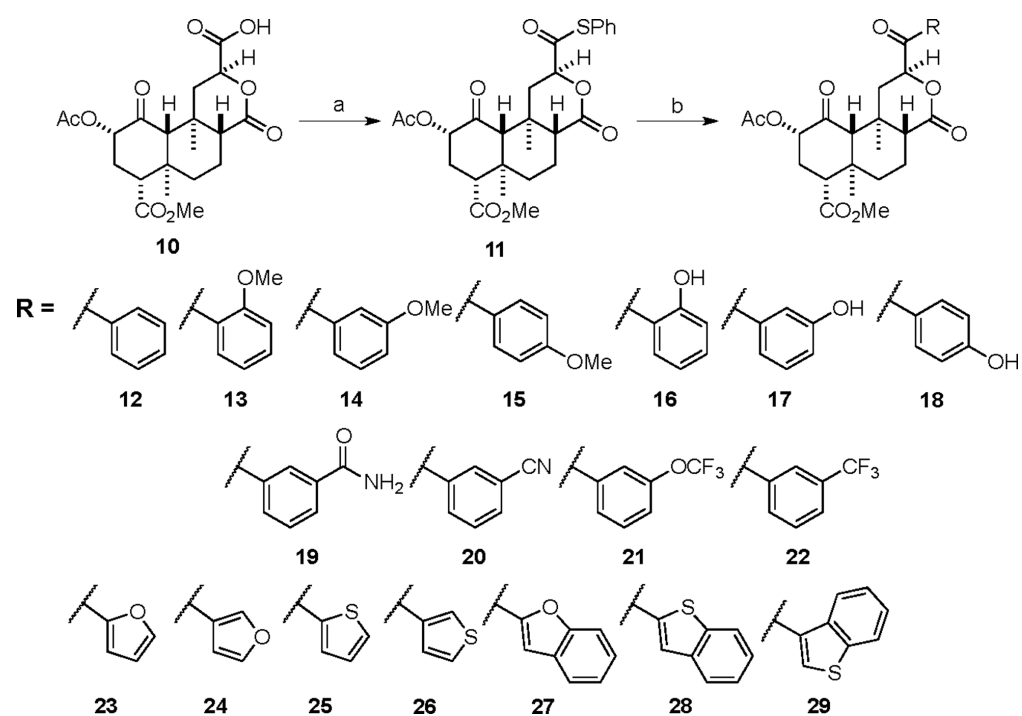

Scheme 3.

${ }^{a}$ Reagents and Conditions: a) CDMT, NMM, thiophenol, $\mathrm{CH}_{2} \mathrm{Cl}_{2}$; b) Appropriate boronic acid, copper thiophene-2-carboxylate (CuTC), $\mathrm{Pd}(\mathrm{dba})_{2}, \mathrm{P}(\mathrm{OEt})_{3}$, THF 


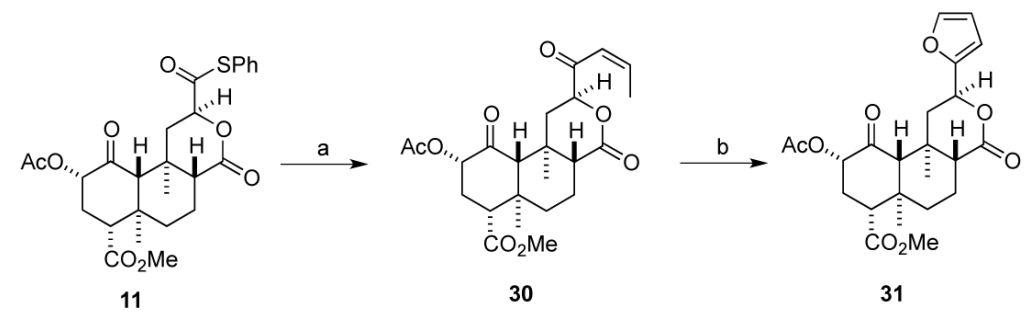

Scheme 4.

${ }^{a}$ Reagents and Conditions: a) cis-1-Propen-1-ylboronic acid, CuTC, $\mathrm{Pd}(\mathrm{dba})_{2}, \mathrm{P}(\mathrm{OEt})_{3}$, THF; b) $\mathrm{SeO}_{2}$, Bromobenzene, reflux 
$\square$ salvinorin A (1)

$\triangle$ 12-epi-1

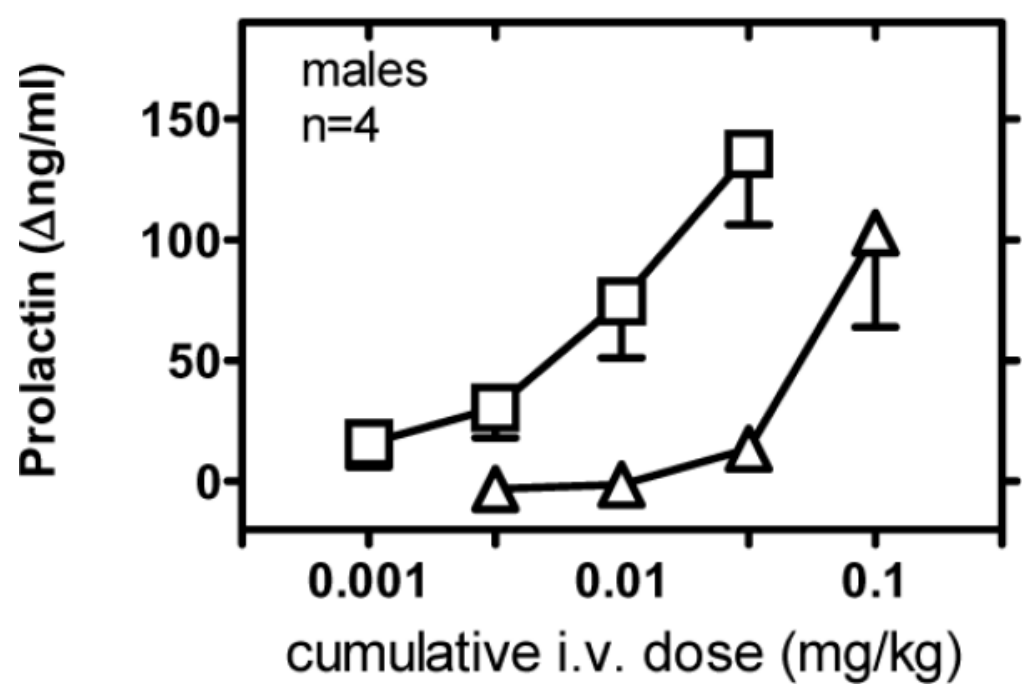

Figure 2.

Dose-effect curve in a neuroendocrine biomarker assay for the effects of i.v.1 and 12-epi-1 (3) on serum prolactin levels in male subjects. Data for $\mathbf{1}$ were from a previous determination under identical experimental conditions. ${ }^{45}$ Abscissa, dose of 1 or $\mathbf{3}$. Ordinate, serum prolactin levels, expressed as change from individual preinjection baseline ( nanograms per milliliter; mean $\pm \mathrm{SEM}$ ). 
Table 1

Opioid receptor binding affinities of neoclerodanes $1,3,9,10$, and $12-31$.

\begin{tabular}{|c|c|c|c|}
\hline \multirow[b]{2}{*}{ Cmpd } & \multirow[b]{2}{*}{ MOP } & \multicolumn{2}{|c|}{$K_{\mathrm{i}} \pm \mathrm{SD}, \mathrm{nM}$} \\
\hline & & DOP & KOP \\
\hline $1^{a}$ & $1,370 \pm 130$ & $>10,000$ & $7.4 \pm 0.7$ \\
\hline 3 & $>10,000(72)^{c}$ & $>10,000(74)^{c}$ & $17 \pm 1^{a}$ \\
\hline 8 & $>10,000(78)^{c}$ & $>10,000(66)^{c}$ & $1,120 \pm 30^{a}$ \\
\hline 9 & $2,600 \pm 140^{a}$ & $>10,000(94)^{c}$ & $30 \pm 4^{a}$ \\
\hline 12 & $1,490 \pm 160^{a}$ & $>10,000(100)^{c}$ & $70 \pm 3^{a}$ \\
\hline 13 & $>10,000(53)^{c}$ & $>10,000(87)^{b}$ & $1,070 \pm 80^{a}$ \\
\hline 14 & $3,090 \pm 260^{a}$ & $>10,000(77)^{b}$ & $290 \pm 10^{a}$ \\
\hline 15 & $>10,000(74)^{c}$ & $>10,000(81)^{b}$ & $>10,000$ \\
\hline 16 & $3,600 \pm 40^{a}$ & $>10,000(94)^{c}$ & $500 \pm 20^{a}$ \\
\hline 17 & $>1,000(55)^{b}$ & $>10,000(80)^{c}$ & $110 \pm 5^{a}$ \\
\hline 18 & $>10,000(93)^{c}$ & $>10,000(100)^{c}$ & $8,470 \pm 900^{a}$ \\
\hline 19 & $>10,000(84)^{b}$ & $>10,000^{b}(52)$ & $40 \pm 1^{a}$ \\
\hline 20 & $>1,000(61)^{b}$ & $>10,000(68)^{b}$ & $220 \pm 10^{a}$ \\
\hline 21 & $4,800 \pm 400^{a}$ & $>1,000(37)^{b}$ & $>10,000(54)^{b}$ \\
\hline 22 & $3,400 \pm 150^{a}$ & $>1,000(46)^{b}$ & $2,260 \pm 120^{a}$ \\
\hline 23 & $9,800 \pm 2,500^{a}$ & $>10,000(91)^{c}$ & $80 \pm 4^{a}$ \\
\hline 24 & $>10,000(66)^{c}$ & $>10,000(95)^{c} \mathrm{xs}$ & $150 \pm 10^{a}$ \\
\hline 25 & $>10,000(65)^{c}$ & $>10,000(99)^{c}$ & $36 \pm 2^{a}$ \\
\hline 26 & $2,530 \pm 250^{a}$ & $>10,000(88)^{c}$ & $31 \pm 3^{a}$ \\
\hline 27 & $>10,000(100)^{c}$ & $>10,000(91)^{c}$ & $>10,000(92)^{c}$ \\
\hline 28 & $>10,000(58)^{c}$ & $>10,000(95)^{c}$ & $9,210 \pm 680^{a}$ \\
\hline 29 & $>1,000(60)^{b}$ & $>1,000(56)^{b}$ & $>10,000(64)^{b}$ \\
\hline 30 & $>1,700^{a}$ & $>5,000^{a}$ & $320 \pm 20^{a}$ \\
\hline 31 & $>1,000(81)^{b}$ & $>10,000(99)^{b}$ & $8.7 \pm 0.4^{a}$ \\
\hline
\end{tabular}

${ }^{a} K_{\mathrm{i}}$ values $( \pm \mathrm{SD})$ were determined from full dose-response curves $(\mathrm{n}=3)$ as described in methods.

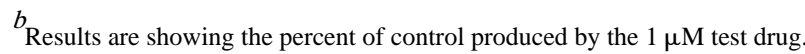

${ }^{c}$ Results are showing the percent of control produced by the $10 \mu \mathrm{M}$ test drug. 
Table 2

Stimulation of $\left[{ }^{35} \mathrm{~S}\right] \mathrm{GTP}-\boldsymbol{\gamma}-\mathrm{S}$ binding to human KOP receptors.

\begin{tabular}{lll}
\hline $\mathbf{C m p d}$ & KOP EC $_{\mathbf{5 0}} \pm \mathbf{S D}^{\boldsymbol{a}}$ & KOP E $_{\mathbf{m a x}} \pm \mathbf{S D}^{\boldsymbol{b}}$ \\
\hline $\mathbf{1}$ & $40 \pm 6$ & $124 \pm 6$ \\
$\mathbf{3}$ & $720 \pm 97$ & $109 \pm 4$ \\
$\mathbf{9}$ & $1,370 \pm 180$ & $105 \pm 4$ \\
$\mathbf{1 2}$ & $2,280 \pm 550$ & $74 \pm 6$ \\
$\mathbf{1 9}$ & $730 \pm 90$ & $92 \pm 4$ \\
$\mathbf{2 3}$ & $2,130 \pm 310$ & $92 \pm 4$ \\
$\mathbf{2 5}$ & $1,630 \pm 230$ & $95 \pm 4$ \\
$\mathbf{2 6}$ & $620 \pm 50$ & $88 \pm 2$ \\
$\mathbf{3 1}$ & $140 \pm 10$ & $104 \pm 2$ \\
\hline
\end{tabular}

${ }^{a}$ EC50 $=$ Effective concentration for 50\% maximal response.

$b_{\mathrm{E}_{\max }}$ is \% which compound stimulates binding compared to (-)-U50,488 at KOP receptors. 
Table 3

Opioid receptor activity measured in the fluorescent $\mathrm{Ca}^{2+}$ mobilization assay.

\begin{tabular}{lll}
\hline Cmpd & KOP EC $_{\mathbf{5 0}} \pm \mathbf{S D}^{\boldsymbol{a}}$ & $\mathrm{KOP} \mathrm{E}_{\mathbf{m a x}} \pm \mathbf{S D}^{\boldsymbol{b}} \boldsymbol{\%}$ \\
\hline $\mathbf{U 6 9 , 5 9 3}^{c}$ & $12.5 \pm 5.4$ & 100 \\
$\mathbf{1}^{d}$ & $6.11 \pm 0.04$ & $97 \pm 5$ \\
$\mathbf{1 9}^{c}$ & $75.4 \pm 21$ & $97 \pm 2$ \\
$\mathbf{3 1}^{c}$ & $12.2 \pm 4.4$ & $97 \pm 8$ \\
\hline
\end{tabular}

${ }^{a}$ EC50 $=$ Effective dose for 50\% maximal response.

${ }^{b} \mathrm{E}_{\max }$ is \% which compound stimulates binding compared to (-)-U69,593 at KOP receptors.

$c_{\mathrm{n}=3}$

$d_{\mathrm{n}=2}$ 